\title{
Return migrants and the wage premium: does the legal status of migrants matter?
}

\author{
Nelly Elmallakh ${ }^{1} \cdot$ Jackline Wahba ${ }^{2}$
}

Received: 2 June 2020 / Accepted: 23 July 2021 / Published online: 07 October 2021

(C) The Author(s) 2021

\begin{abstract}
This paper examines the impact of the legal status of overseas migrants on their wages upon return to the home country. Using unique data from Egypt, which allows us to distinguish between return migrants according to whether their international migration was documented or undocumented, we examine the impact of illegal status on wages upon return. Relying on a Conditional Mixed Process model, which takes into account the selection into emigration, into return, and into the legal status of temporary migration, we find that, upon return, undocumented migrants experience a wage penalty compared with documented migrants, as well as relative to non-migrants. Our results are the first to show the impact of undocumented migration on the migrant upon return to the country of origin.
\end{abstract}

Keywords Return migration · Undocumented migration · Illegality · Wages · Egypt

JEL Classification F22 · J30

\section{Introduction}

Migration has become an increasingly politicized issue, in particular given the rise in unauthorized migration, igniting public and policy interest in its impacts and sparking

Responsible editor: Shuaizhang Feng

We would like to thank the editor Shuaizhang Feng, the managing editor Madeline Zavodny, and three anonymous referees for their valuable feedback. The authors also wish to thank Albrecht Glitz, Mark D. Hayward, Lawrence M. Kahn, Erik Lindqvist, and Giovanni Peri for useful comments.

$\triangle$ Jackline Wahba

j.wahba@soton.ac.uk

Nelly Elmallakh

nelmallakh@worldbank.org

1 World Bank, Washington D.C., USA

2 Department of Economics, University of Southampton, Southampton, UK 
new debates on the relationship between migration and economic development. Not surprisingly, the focus of the academic literature on unauthorized migration has been on the impact of irregularity on the host country. However, little is known about the consequences of irregular migration on sending countries. Studying the impact of illegality on the origin country is particularly important since unauthorized migration is often temporary, and many irregular migrants return to their home country either because they are deported or because they planned on temporary migration all along.

Return migration is an important phenomenon in the broad picture of international mobility. Although statistics on return migration are not reliable, recent estimates are that roughly one-quarter of all migration events are returns (Azose and Raftery 2019). According to the OECD (2018), the five countries that experienced the largest outflows of foreign populations in 2016 were Germany (1.09 million), Korea $(325,000)$, Spain $(243,000)$, Japan $(234,000)$, and the UK $(195,000)$. At the same time, irregular migration has been on the rise. According to the European Commission, every year, between 400,000 and 500,000 foreign nationals are ordered to leave the European Union because they have either entered or stayed irregularly in the destination country.

Irregular migration is not only an issue for OECD countries, but is also a challenge for the Gulf states and middle-income countries like Malaysia and Thailand. For example, the United Nations Office for Drugs and Crime (UNODC) estimates that every year more than 660,000 people migrate irregularly to Thailand (Schloenhardt 2014). Another example is Mexico, known for being a major migrantsending country to the USA, for its unauthorized emigration, and for its substantial return migration flows. According to the Mexican National Survey of Demographic Dynamics (ENADID), between 2009 and 2014, about half (48\%) of the Mexican immigrant population in the USA was unauthorized, and one million Mexicans returned from the USA, leaving of their own accord (Gonzalez-Barrera 2015). ${ }^{1}$ Many other developing countries are likewise experiencing high return migration rates, as well as an increase in unauthorized emigration.

This paper is the first to examine the impact of undocumented migration status on migrants upon return to their home country. It investigates an unexplored question, namely the impact of the legal status of migrants on their wages upon return. We study the impact of return migration on wages by disentangling the effects of overseas legal versus illegal status and ask whether undocumented temporary migration has any impact on human capital accumulation that persists after return. From a conceptual point of view, temporary migrants might acquire human capital and skills due to their work experience abroad and hence earn higher wages upon return compared to non-migrants. However, whether all migrants, documented or undocumented, would benefit from their migration experience upon return is not straightforward. On one hand, if illegal status hinders the human capital accumulation and the skill acquisition of undocumented migrants, the well-evidenced wage premium witnessed by migrants upon return might not apply and we might expect that only documented

\footnotetext{
1 See Massey and Singer (1995) for an estimation of the probability of border apprehension and undocumented Mexican migration in the USA between 1965 and 1989.
} 
migrants would benefit from their migration experience. On the other hand, the origin country's labor market might reward the migration experience regardless of the documented or undocumented nature of migration. If the latter scenario applies, through a signaling mechanism, all migrants would benefit from their experience overseas, regardless of the nature of migration and/or of the human capital and skills acquired abroad.

We contribute to the literature on undocumented migration, which is rather sparse given the lack of data. Hanson (2006) provides a survey of the determinants of illegal migration to the USA, focusing on the role of immigration policy and enforcement. Orrenius and Zavodny (2003) examine the impact of amnesty programs on undocumented immigration flows, while Orrenius and Zavodny (2005) study the effect of changes in border enforcement policies on the skill level of undocumented Mexican immigrants in the USA.

A few papers have examined the return intentions of undocumented migrants. For instance, Vinogradova (2016) provides theoretical explanations for the optimal timing of return of undocumented migrants, whereby the threat of deportation increases uncertainty with respect to the length of the stay abroad, which in turn reduces the desired migration duration and triggers voluntary return. In line with this theoretical argument, several papers find that a significant share of unauthorized migrants intend to immigrate only temporarily and to eventually return to their home country (Borjas et al. 1991). Reyes (2001) finds that undocumented Mexican immigrants are much more likely to return than documented ones. Coniglio et al. (2009) find that more than $70 \%$ of irregular immigrants to Italy planned to return home after an average intended stay of 6 years and that high-skilled clandestine migrants are more likely to return to the origin country compared with those with no or low skills. On the other hand, other studies have found lower return rates among undocumented immigrants due to stricter border enforcement (Kemnitz and Mayr 2012; Massey et al. 2016).

Focusing on the impact of illegality on the migrant, the literature has focused on a myriad of outcomes, including the labor market outcomes of undocumented migrants and their consumption behavior. ${ }^{2}$ Under an Italian amnesty program, Devillanova et al. (2018) find that immigrants who are potentially eligible for legal status are more likely than ineligible undocumented immigrants to be employed. Using the 1990 Legalized Population Survey, Rivera-Batiz (1999) estimate a 52\% wage penalty for Mexican undocumented immigrants in the USA, while Kossoudji and Cobb-Clark (2002) report a wage penalty that ranges between 14 and 24\%. Phillips and Massey (1999) find that the Immigration Reform and Control Act in the USA, which made it illegal to hire unauthorized immigrants, is associated with a larger wage penalty for undocumented migrants as employers pass the costs of unauthorized hiring on to workers. Accounting for selection, Schluter and Wahba (2009) also find a significant effect of illegality on wages in the host country but mixed effects on remitting behavior. On the other hand, Dustmann et al. (2017) find that undocumented migrants

\footnotetext{
2 Other papers have examined the impact of undocumented immigration on the earnings of other workers. Bean et al. (1988) find a positive effect of undocumented Mexican migration on the wages of other workers, while documented immigrants have a negative effect on natives' earnings. The authors argue that undocumented Mexican immigrants' jobs complement those of other workers.
} 
consume about $40 \%$ less than documented migrants in Italy, partly due to their lower incomes relative to documented migrants.

The literature has put forward several explanations for the worse outcomes experienced by undocumented migrants compared with documented migrants. First, several studies show that undocumented migrants have weak bargaining power due to the lack of legal work options. Without viable outside options, undocumented migrants are confined into poor jobs (Gonzales 2011; Gleeson and Gonzales 2012). For instance, undocumented migrants are more likely to work in physically exhausting and dangerous jobs and receive no compensating differential, which is analogous to receiving lower wages than documented workers with similar education levels (Hall and Greenman 2015). Second, the occupational choices of undocumented migrants might be limited by fear of exposure to apprehension by immigration enforcement agencies, and relatedly, being undocumented may limit workers' ability to maximize their potential, which may lead to lower productivity (Ortega and Hsin 2018). Third, several studies highlight the increased risk of depression and anxiety among undocumented migrants-due to the threat of deportation and poorer labor market conditions-which is also likely to negatively affect worker productivity (Abrego 2011; Gonzales 2011; Patler and Pirtle 2018).

There is also a well-established academic literature on the determinants and impacts of migration on countries of origin. Indeed, there is a growing body of evidence showing that temporary migration can be beneficial for migrants who accumulate savings and skills, which they use to better themselves upon return (see Wahba (2014) for a survey of this literature). On the impact of temporary migration experiences on return migrants' wages, several papers find that there is a positive wage premium for return migrants associated with overseas work experience (Co et al. 2000; De Coulon and Piracha 2005). Ambrosini et al. (2015) find that for a source country, like Romania, relatively high rates of temporary migration have positive long-run effects on average skills and wages. Lacuesta (2010) finds an 11\% wage gap between returning migrants and observationally equivalent non-migrants in Mexico, but argues that this premium is the result of pre-migration differences in ability and not the result of human capital gains derived from migration. Reinhold and Thom (2013) also find a wage premium for Mexican returnees who worked in the USA. The return to a year of occupation-specific migration experience is estimated to be as high as $9 \%$ for some occupations. De Vreyer et al. (2010) examine the labor market outcomes of returnees in seven capital cities in West Africa and find that experience abroad results in a substantial wage premium for migrants returning from an OECD country but not for other return migrants. Controlling for the emigration and return migration selections, Wahba (2015) finds that return migrants experience a wage premium of $16 \%$ relative to non-migrants. However, none of these studies has examined the differential effects of return migration on wages with respect to migrants' legal status.

Our paper contributes to the literature in at least two ways. Firstly, while the literature on undocumented migration has focused on the impact of irregularity on destination countries, this paper is the first to investigate the impact of undocumented migration on migrants after they return to their origin country. This is particularly 
important since many unauthorized migrants return to their country of origin. Secondly, by disentangling the effects of migrants' legal status, we contribute to the literature on the impacts of migration on origin countries, which has so far overlooked the question of undocumented migration.

We use data from the Egypt Labor Market Panel Survey (ELMPS 2012), which has several major advantages. First, Egypt provides a particularly suitable case study since it is a country with substantial return migration. According to the ELMPS data, in 2012, 9\% of individuals between the ages of 15 and 59 were return migrants. ${ }^{3}$ This figure is in line with the World Bank report by Brodmann et al. (2010), who document that Egyptian migrants constitute $85 \%$ of temporary workers in Arab countries, representing as much as $10 \%$ of the Egyptian labor force in recent years. Based on the Development Economics Group data from the World Bank, Brodmann et al. (2010) show that, in 2005, Egypt was among the top 10 emigration countries in the world. Second, our data provides unique information on migrants' legal status while abroad, which allows us to distinguish between return migrants according to their type of international migration-documented versus undocumented. Return migrants were asked whether they had a visa or legal document to enter the destination country, as well as the type of document they had.

In this paper, illegal status/undocumented migration refers to unauthorized entry, stay, or employment in a country. ${ }^{4}$ Generally speaking, misreporting information regarding migrants' legal status is problematic. This is especially the case for studies that examine the impact of illegality from the perspective of the destination country, where migrants are asked-during ongoing migration spells-about their legal status. However, in our context, the issue of misreporting is much less of a concern since migrants have already returned to their origin country and there would be no repercussions at that stage.

Our empirical analysis relies on a Conditional Mixed Process (CMP) model, following Roodman (2011). The CMP model takes into account the triple selection into emigration, into illegality, and into return migration, and allows us to estimate the effect of overseas illegal status on wages after return. We find that undocumented migrants witness a wage penalty relative to documented migrants but also relative to non-migrants, while only documented migrants witness a wage premium relative to non-migrants. Our benchmark results show an estimated $19 \%$ wage penalty for illegal migrants relative to non-migrants, while documented migrants witness a wage premium of $28 \%$ relative to non-migrants. Therefore, the wage penalty for undocumented migrants relative to documented migrants is estimated to be around $47 \%$. However, we do not find any effect of migrants' legal status on occupations or on labor supply upon return to Egypt.

We investigate several underlying mechanisms that could be driving the undocumented migrants' poorer labor market prospects upon return. We examine the effect

\footnotetext{
3 Using the ELMPS 2018, we also find high rates of return migration. For example, in 2018, we find that $7.4 \%$ of households had a return migrant. We also find that $7.1 \%$ of individuals between the ages 15 and 59 and $9.2 \%$ of men between the ages 15 and 59 were return migrants in 2018 .

4 We note the use of the terms undocumented and illegal interchangeably to refer to migrant status, in the rest of the paper.
} 
of migrants' undocumented status on various outcomes pertaining to the migration experience overseas. We find suggestive evidence of an overseas wage penalty associated with illegality, as our results show that undocumented migrants earn approximately half the wage of documented migrants while abroad. Moreover, our results suggest that undocumented migrants have significantly lower savings overseas, shorter migration duration, lower incidence of remitting, and lower ranked occupations overseas. Overall, these findings suggest that undocumented migrants' lower earnings after return might be explained by a waste of human capital overseas. Indeed, we find evidence suggesting that the longer undocumented migrants stay abroad, the more their human capital is depleted, while the opposite is true for documented migrants. This is fully consistent with our descriptive analysis that shows that poor working conditions constitute the most important reason for return migration among undocumented migrants.

This paper sheds light on the potential costs and penalties of unauthorized overseas work and migration. Our results contest the positive wage premium evidenced in the existing literature, and suggest that the positive impact of temporary migration experience on wages upon return is conditional on the type of migration undertaken and that only documented migrants benefit from their migration experience in terms of higher wages upon return to their home country. Understanding the impacts of undocumented migration on the migrant and the origin country is indeed paramount as the results of this paper suggest that the impact of temporary migration might actually depend on the legal status of the migrants. Therefore, ignoring the legal status of migration and its impact is likely to lead to erroneous policies.

The rest of this paper is organized as follows. Section 2 provides a brief description of Egyptian migration, while Section 3 presents the data. Section 4 describes our empirical model and identification strategy. Section 5 presents the results and tests for various underlying mechanisms. Section 6 provides robustness checks, while Section 7 concludes.

\section{Background on Egyptian migration}

Egypt is an ideal setting for our analysis given the importance of return migration. Egypt has been a main labor sending country since the 1970s. The largest boost to migration flows occurred after the 1973 War, when oil revenues quadrupled and Gulf countries started implementing major development programs. Ever since Egypt has experienced regular outflows of its workers. To a large extent, this was triggered by the labor shortages in the oil-producing Gulf countries and the increased demand for foreign labor. The majority of Egyptian migrants went to neighboring Arab states: to oil exporting Arab countries (the Gulf states, Libya, and Iraq) and to non-oil exporting Arab countries (Jordan and Lebanon) to replace nationals of those countries who migrated to the Gulf. A small proportion of Egyptian migration is permanent in nature and is destined to North America and Australia. More recently, after the $2011 \mathrm{Arab}$ Spring and the economic slowdown that followed, Egyptian migration to Europe has increased (De Bel-Air 2016). 
According to the Egyptian Ministry of Foreign Affairs, the number of Egyptians abroad was estimated to be 6.5 million at the beginning of 2011. Overall, Egyptian migration is temporary in nature and is male dominated, as Egyptians typically migrate to seek overseas employment. The Gulf Cooperation Council (GCC) countries hire migrant labor under the sponsorship (kefala) system, where permanent residency and citizenship are precluded to foreign nationals. Many Egyptians are undocumented workers in the GCC countries, and in other Arab neighboring countries like Jordan, which constitute the main destinations for Egyptian migrants. Irregular migration in the GCC countries takes two forms: overstay and informal employment, defined as employment for purposes other than those for which entry was authorized (Awad and Aziz 2017). Finally, in the case of Jordan, Egyptians do not need an entry visa but are required to have a contract before working there.

\section{The data}

\subsection{The ELMPS survey}

For the empirical analysis, we use data from the Egypt Labor Market Panel Survey (ELMPS). ${ }^{5}$ The ELMPS is a rich wide-ranging nationally representative survey carried out by the Economic Research Forum (ERF) in cooperation with Egypt's Central Agency for Public Mobilization and Statistics (CAPMAS) since 1998. In this paper, we focus particularly on the 2012 round (ELMPS 2012). As in a typical labor force survey, the ELMPS covers topics such as employment, unemployment, job dynamics, and earnings but also provides very rich information on education, migration, and socio-economic characteristics. In 2012, the ELMPS interviewed 12,060 households, which yields to a total sample size of 49,186 individuals. The ELMPS 2012 includes a refresher sample of 2,000 households that was selected from an additional 200 Primary Sampling Units (PSUs) randomly selected from a new master sample prepared by CAPMAS. By design, it oversampled areas with high migration rates, and is nationally representative once weights are applied (Assaad and Krafft 2013). ${ }^{6}$

We rely on the return migration module that surveys all individuals aged between 15 and 59 years old. In 2012, about $10 \%$ of the households had a returnee. In the ELMPS, a returnee is defined as an individual who has worked abroad for more than 6 months, but was back in Egypt at the time of the survey. This module features return migrants' characteristics, incidences of migration, reasons for migration, financial situation before migration, year and country of first migration episode, year of final

\footnotetext{
5 See OAMDI (2016) for data documentation.

6 In every wave of the survey, a refresher sample of 2,000-3,000 observations is included to allow for a more in-depth examination of phenomena of interest. While the 2012 round oversampled high-migration areas, the 2018 round included a refresher sample of 2,000 households to oversample rural communities that were among the 1,000 poorest villages of Egypt (Krafft et al. 2019). The 2012 round is therefore advantageous for our analysis as it oversampled areas with high migration rates, which allows us to have a larger sample on migrants and to better disentangle the effect of illegality. In Section 6, we also rely on the 2018 round and show that our results are fully robust to using more recent data.
} 
return, earnings and savings abroad, and remittances, as well as documents obtained to travel and work abroad. In addition, the ELMPS 2012 collects rich retrospective information on previous employment characteristics and their location. At the same time, households are asked about current members of the household who were overseas at the time of the survey, and collects information on their overseas destination, overseas employment, migration duration, and frequency of contact/visits to the household back home.

\subsection{Non-migrants versus return migrants}

We focus on working-age men, aged 15 to 59 years old at the time of survey, as Egyptian migration is mostly male dominated. In Table 1 , we report descriptive statistics on the sample of non-migrants (individuals who never migrated) and return migrants (individuals who migrated for work purposes and returned to Egypt). The two groups of individuals are significantly different along a set of individual, geographical, and job characteristics. Returnees are found to be significantly older compared to nonmigrants, and also significantly more likely to be married. Returnees are also found to be more likely to have secondary education but less likely to have above secondary education compared to non-migrants. The incidence of rural residence is also significantly higher among return migrants compared to non-migrants.

In terms of geographical locations, returnees are found to be less likely to live in Cairo, Alexandria, Canal cities, and urban Upper Egypt, and significantly more likely to live in rural Lower Egypt. ${ }^{7}$ Returnees also have greater job tenure compared to non-migrants and we find that the incidence of having a work contract is also higher among return migrants. In terms of sectors of employment, returnees are significantly more likely to be employed in the public sector for their job in 2012 compared to non-migrants. In terms of economic activities, we find that non-migrants are significantly more likely to be employed in manufacturing, mining, and quarrying, and in wholesale and retail trade compared to return migrants.

\subsection{Defining undocumented migration}

In the ELMPS 2012, return migrants were asked whether they had a visa or official document to enter the destination country during the first migration episode, as well as the type of document they had. ${ }^{8}$ Relying on this information, we are able to identify documented and undocumented migrants among the pool of return migrants. For

\footnotetext{
7 Elmallakh and Wahba (2021a) also examine the geographical transition matrices for non-migrants and return migrants. We examine individuals' mobility between their region of birth and their region of residence, at the time of the survey, in order to investigate whether the geographical locations reported in Table 1 reflect settlement choices after return or whether returnees are simply returning to their regions of origin. We find evidence of little mobility for both groups - the mobility rates are equal to 5.5\% and $7.1 \%$ for non-migrants and return migrants, respectively. The descriptive statistics on geographical locations in Table 1 therefore do not reflect relocation choices, as the results suggest that return migrants eventually return to their origin regions.

8 This question is similar to what was used in the Mexican Migration Project questionnaire to elicit information on the documentation the migrant had.
} 
Table 1 Descriptive statistics: Non-migrants and returnees who are wage earners

\begin{tabular}{|c|c|c|c|c|c|}
\hline & \multicolumn{2}{|c|}{ Non-migrants } & \multicolumn{2}{|c|}{ Return migrants } & \multirow[b]{2}{*}{ (5) } \\
\hline & (1) & (2) & (3) & (4) & \\
\hline & Mean & St. Dev. & Mean & St. Dev. & Difference \\
\hline \multicolumn{6}{|l|}{ Individual characteristics } \\
\hline Age & 34.055 & 10.679 & 42.458 & 9.939 & $-8.403 * * *$ \\
\hline Ever-married & 0.740 & 0.439 & 0.949 & 0.221 & $-0.209 * * *$ \\
\hline No educational degree & 0.189 & 0.392 & 0.195 & 0.396 & -0.005 \\
\hline Primary or preparatory education & 0.182 & 0.385 & 0.142 & 0.349 & $0.040 * * *$ \\
\hline Secondary education & 0.382 & 0.486 & 0.484 & 0.500 & $-0.102 * * *$ \\
\hline Above secondary education & 0.247 & 0.431 & 0.179 & 0.384 & $0.068 * * *$ \\
\hline Rural & 0.531 & 0.499 & 0.638 & 0.481 & $-0.108 * * *$ \\
\hline \multicolumn{6}{|l|}{ Geographical regions } \\
\hline Cairo & 0.121 & 0.326 & 0.079 & 0.270 & $0.041 * * *$ \\
\hline Alexandria and Canal cities & 0.099 & 0.298 & 0.049 & 0.215 & $0.050 * * *$ \\
\hline Urban Lower Egypt & 0.106 & 0.308 & 0.127 & 0.333 & $-0.020^{*}$ \\
\hline Urban Upper Egypt & 0.145 & 0.352 & 0.110 & 0.313 & $0.035^{* * *}$ \\
\hline Rural Lower Egypt & 0.278 & 0.448 & 0.385 & 0.487 & $-0.108 * * *$ \\
\hline Rural Upper Egypt & 0.251 & 0.434 & 0.250 & 0.434 & 0.001 \\
\hline \multicolumn{6}{|l|}{ Current job characteristics } \\
\hline Job tenure & 11.732 & 9.604 & 12.654 & 9.293 & $-0.922 * *$ \\
\hline Incidence of work contract & 0.420 & 0.494 & 0.488 & 0.500 & $-0.068 * * *$ \\
\hline \multicolumn{6}{|l|}{ Sector of employment } \\
\hline Public sector & 0.319 & 0.466 & 0.435 & 0.496 & $-0.116^{* * *}$ \\
\hline Private sector & 0.656 & 0.475 & 0.551 & 0.498 & $0.105^{* * *}$ \\
\hline Other sector & 0.025 & 0.156 & 0.014 & 0.117 & $0.011 *$ \\
\hline \multicolumn{6}{|l|}{ Economic activities } \\
\hline Agriculture, forestry, fishing & 0.116 & 0.320 & 0.118 & 0.323 & -0.003 \\
\hline Manufacturing, mining, quarrying & 0.195 & 0.396 & 0.129 & 0.336 & $0.065 * * *$ \\
\hline Construction & 0.164 & 0.370 & 0.185 & 0.389 & -0.021 \\
\hline Wholesale, retail trade, and transportation & 0.237 & 0.425 & 0.160 & 0.367 & $0.077 * * *$ \\
\hline Professional and administrative activities & 0.023 & 0.151 & 0.024 & 0.152 & 0.000 \\
\hline Other activities & 0.265 & 0.442 & 0.384 & 0.487 & $-0.118^{* * *}$ \\
\hline Observations & 7,437 & & 719 & & \\
\hline
\end{tabular}

*** $p<0.01$; ** $p<0.05$; * $p<0.1$

Column 5 is $t$-test for whether the difference in means between the two groups is statistically significant 
most of the destination countries, Egyptian migrants are required to have a visa. For a few countries, like Sudan, Libya, Jordan, Lebanon, and Yemen, Egyptians are not required to have a visa or can ask for a visa on arrival.

We define undocumented migrants as those who entered the destination country without having a visa or official document, for countries that required an entry visa, or as those who did not have a work contract for their employment abroad, for countries that did not require an entry visa. This definition accounts for over-stayers in destination countries that have a visa waiver for Egyptians since an over-stayer who is working in these countries is likely to work as an undocumented worker, i.e., without a work contract. However, for countries that require an entry visa, an undocumented immigrant could have entered legally the destination country with a visa and over-stayed beyond the period for which admission was granted. Thus, to account for over-stayers in countries that require Egyptians to have a visa, we additionally consider as undocumented migrants those who entered the destination country with a work permit, a tourist visa, a visit visa or a temporary residence permit, and were working in the destination country without work contract. ${ }^{9}$ Therefore, an undocumented migrant (1) is a migrant who did not have a visa or official document to enter the destination country if the country required an entry visa, (2) was working without a work contract for countries that had a visa waiver for Egyptians, or (3) had a work permit, a tourist visa, a visit visa, or a temporary residence permit but was working in the destination without any work contract (to potentially capture over-stayers).

\subsection{Documented versus undocumented migrants}

In our definition of undocumented migration, we focus on the first migration episode, since all the information provided in the dataset on the migrants' legal status to enter the destination country is relative to the first migration. ${ }^{10}$ In Table 2 , we focus on the sample of returnees and compare returnees who had a legal migration status when they entered the destination country during their first migration episode to those who had an illegal migration. An important difference between documented and undocumented migrants is their level of educational attainment. Documented migrants are significantly more likely to have an above secondary education compared to undocumented migrants, while undocumented migrants are more likely to have no educational degree. In terms of geographical regions, documented migrants are more likely to live in Cairo and Upper Egypt, both urban and rural, whereas, undocumented migrants are more likely to live in rural Lower Egypt. As for their job in 2012 upon return, undocumented migrants have greater job tenure by approximately 2 years and are significantly less likely to have a work contract compared

\footnotetext{
9 This definition of undocumented migration also partly addresses concerns about the possibility of misreporting of overseas legal status, since it attempts to capture over-stayers.

10 It is important to note that the incidence of multiple migration episodes is very low in Egypt. In our dataset, $80 \%$ of return migrants had one migration episode, $15 \%$ had two migration episodes, and less than $5 \%$ had more than two migration episodes. For robustness, Elmallakh and Wahba (2021a) also exclude individuals who had more than two migration episodes.
} 
Table 2 Descriptive statistics: Documented versus undocumented return migrants

\begin{tabular}{|c|c|c|c|c|c|}
\hline & \multicolumn{2}{|c|}{$\begin{array}{l}\text { Documented } \\
\text { migrants }\end{array}$} & \multicolumn{2}{|c|}{$\begin{array}{l}\text { Undocumented } \\
\text { migrants }\end{array}$} & \multirow[b]{2}{*}{ (5) } \\
\hline & (1) & (2) & (3) & (4) & \\
\hline & Mean & St. Dev. & Mean & St. Dev. & Difference \\
\hline \multicolumn{6}{|l|}{ Individual characteristics } \\
\hline Age & 42.332 & 9.736 & 42.652 & 10.260 & -0.321 \\
\hline Ever-married & 0.950 & 0.219 & 0.947 & 0.225 & 0.003 \\
\hline No educational degree & 0.169 & 0.375 & 0.234 & 0.424 & $-0.065^{* *}$ \\
\hline Primary or preparatory education & 0.149 & 0.356 & 0.131 & 0.338 & 0.018 \\
\hline Secondary education & 0.462 & 0.499 & 0.518 & 0.501 & -0.055 \\
\hline Above secondary education & 0.220 & 0.415 & 0.117 & 0.322 & $0.103 * * *$ \\
\hline Rural & 0.600 & 0.491 & 0.699 & 0.460 & $-0.099 * * *$ \\
\hline \multicolumn{6}{|l|}{ Geographical regions } \\
\hline Cairo & 0.103 & 0.304 & 0.043 & 0.202 & $0.060 * * *$ \\
\hline Alexandria and Canal cities & 0.050 & 0.219 & 0.046 & 0.210 & 0.004 \\
\hline Urban Lower Egypt & 0.124 & 0.329 & 0.131 & 0.338 & -0.008 \\
\hline Urban Upper Egypt & 0.128 & 0.335 & 0.082 & 0.274 & $0.047 *$ \\
\hline Rural Lower Egypt & 0.304 & 0.461 & 0.511 & 0.501 & $-0.206^{* * *}$ \\
\hline Rural Upper Egypt & 0.291 & 0.455 & 0.188 & 0.391 & $0.103 * * *$ \\
\hline \multicolumn{6}{|l|}{ Current job characteristics } \\
\hline Job tenure & 11.847 & 8.909 & 13.904 & 9.743 & $-2.058 * * *$ \\
\hline Incidence of work contract & 0.501 & 0.501 & 0.468 & 0.500 & 0.033 \\
\hline \multicolumn{6}{|l|}{ Sector of employment } \\
\hline Public sector & 0.435 & 0.496 & 0.436 & 0.497 & -0.001 \\
\hline Private sector & 0.551 & 0.498 & 0.550 & 0.498 & 0.002 \\
\hline Other sector & 0.014 & 0.117 & 0.014 & 0.118 & 0.000 \\
\hline \multicolumn{6}{|l|}{ Economic activities } \\
\hline Agriculture, forestry, fishing & 0.121 & 0.327 & 0.113 & 0.318 & 0.008 \\
\hline Manufacturing, mining, quarrying & 0.128 & 0.335 & 0.131 & 0.338 & -0.003 \\
\hline Construction & 0.181 & 0.385 & 0.191 & 0.394 & -0.011 \\
\hline Wholesale, retail trade, and transportation & 0.162 & 0.369 & 0.156 & 0.364 & 0.006 \\
\hline Professional and administrative activities & 0.023 & 0.150 & 0.025 & 0.156 & -0.002 \\
\hline Other activities & 0.384 & 0.487 & 0.383 & 0.487 & 0.001 \\
\hline Observations & 437 & & 282 & & \\
\hline
\end{tabular}

*** $p<0.01$; ** $p<0.05$; * $p<0.1$

Column 5 is $t$-test for whether the difference in means between the two groups is statistically significant 
Table 3 Average hourly wages for non-migrants, returnees by legal status

\begin{tabular}{lll}
\hline & $\begin{array}{l}\text { Average hourly wage } \\
\text { (Standard deviation) }\end{array}$ & $\begin{array}{l}\text { Difference with respect to non-migrants } \\
(p \text {-value })\end{array}$ \\
\hline Non-migrants & 6.257 & - \\
$(N=7,437)$ & $(12.446)$ & 0.644 \\
Returnees & 6.901 & $(0.184)$ \\
$(N=719)$ & $(11.928)$ & 0.848 \\
Documented migrants & 7.104 & $(0.167)$ \\
$(N=437)$ & $(12.824)$ & 0.328 \\
Undocumented migrants & 6.585 & $(0.662)$ \\
$(N=282)$ & $(10.402)$ & \\
\hline
\end{tabular}

In the first column, average hourly wages for non-migrants, returnees, and documented and undocumented migrants are reported in Egyptian pounds for the current job in 2012, as well as standard deviation in brackets. In the second column, differences with respect to the group of non-migrants and the associated $p$-value for a $t$-test of whether the difference between the two groups is statistically significant

to documented migrants. Along the spectrum of sectors of employment and economic activities, both documented and undocumented migrants seem to be equally employed in the different economic sectors and activities.

In Table 13 in the Appendix, we examine additional differences between documented and undocumented migrants with respect to their migration spell abroad. Documented migrants are found to have significantly higher monthly earnings and savings while abroad. They are also more likely to remit and to send higher remittances compared to undocumented migrants. In addition, documented migrants are found to have longer migration spells relative to undocumented migrants, by 1 year on average. However, there is no significant difference in terms of number of migration episodes between the two groups-as they both seem on average to have one migration spell. In the 1980s, a significantly higher proportion of undocumented migrants migrated compared to documented migrants. By contrast, in the 1990s and in the 2000s, a higher proportion of documented migrants migrated for the first time compared to undocumented migrants. In terms of destination choice, undocumented migrants were significantly more likely to choose Libya and Iraq. However, documented migrants were found to be significantly more likely to migrate to Saudi Arabia, United Arab Emirates, Kuwait, and other destination countries. ${ }^{11}$

Looking at the average hourly wages in 2012 for non-migrants, returnees, documented and undocumented migrants in Table 3, we find that the average hourly wage for returnees is higher than non-migrants. ${ }^{12}$ We also find that documented migrants have higher hourly wages compared to undocumented migrants upon return. In the second column, we report the difference in hourly wages between each group and

11 Other destination countries include the USA, the UK, Netherlands, France, Austria, Czech Republic, Italy, Greece, Cyprus, Bulgaria, Romania, Iceland, Uganda, Mozambique, Morocco, Algeria, Sudan, Syria, Lebanon, Palestine, Yemen, Bahrain, Qatar, Oman, and Japan.

12 It is important to note that returnees include both documented and undocumented migrants. 
non-migrants. Indeed, we find that the difference in hourly wages between documented migrants and non-migrants is the largest, while we find that the difference in hourly wages between undocumented migrants and non-migrants is the smallest.

\section{Empirical strategy}

\subsection{The empirical model and identification}

We estimate the effect of the legal status of migrants on their wages upon return by using a relatively new estimation technique - a Conditional Mixed Process (CMP) estimator-following Roodman (2011). The CMP model jointly estimates two or more equations with correlations in the error processes, while the dependent variables may or may not be correlated within this system of equations. The modeling framework of CMP is essentially similar to fitting a Seemingly Unrelated Regression (SUR) model. However, the standard SUR consistently estimates models with continuous dependent variables using OLS and requires the error term in each equation to have a zero conditional mean. The latter assumption in SUR rules out simultaneity or the presence of endogenous variables. The CMP model, on the other hand, estimates mixed processes, i.e., it does not require classical continuous dependent variables. It offers a broad spectrum to estimate different types of dependent variables including binary, categorical, or censored outcomes.

As opposed to SUR, the CMP modeling framework can fit instrumental variables system to deal with endogeneity or simultaneity, and is therefore appropriate to estimate multi-equation models in which endogenous variables appear on the right-hand side of other equations. Moreover, the CMP model is conditional on the data as it allows the different equations in the model to vary by observations. This means that equations can be estimated on different samples which may or may not overlap. For structural models in which the data-generating process is fully modeled, CMP is full information maximum likelihood estimator (FIML), while CMP is limited information maximum likelihood (LIML) for models in which some equations are structural and other equations are reduced forms, as in $2 \mathrm{SLS}$, to provide instruments for identification of the parameters in the structural equations.

We estimate the effect of migrants' legal status on their wages upon return by taking into account the selection into migration, the selection into legal status, and the selection into return. Our structural equation-in which we estimate the effect of illegality on wages - is therefore augmented with reduced form equations to account for these various layers of selection.

In our structural equation, $W_{i}$ denotes the logarithm of hourly wages in 2012 upon return to Egypt. We fit two distinct equations. In equation (1a), we estimate the effect of illegality conditional on being a return migrant on wages upon return, where $M_{i}$ denotes the probability of migration. Our sample therefore consists of return migrants and we compare migrants with illegal status to those with legal status. In equation (1b), we estimate instead the effect of illegality and legality, unconditional on return 
migration. Thus, our sample consists of return migrants and non-migrants, which allows us to compare migrants with illegal status to those with legal status relative to non-migrants.

$$
\begin{array}{r}
\left.W_{i}=\delta_{0}+\delta_{1} \text { (Illegal }_{i} \mid M_{i}=1\right)+\delta_{2} X_{i}+\delta_{3} Z_{i}+v_{i} \\
W_{i}=\delta_{0}+\delta_{1} \text { Illegal }_{i}+\delta_{2} \text { Legal }_{i}+\delta_{3} X_{i}+\delta_{4} Z_{\mathrm{i}}+v_{i}
\end{array}
$$

Our regressions control for the vector $\left(X_{i}\right)$ for individual characteristics, which includes individual's age and its squared term, a dummy variable for rural residence, highest level of educational attainment dummies (no educational degree, primary or preparatory education, and secondary education), and parental controls (a dummy for having an illiterate father or mother, a dummy for having a wage-worker father, and a dummy for having a wage-worker mother). In equations (1a) and (1b), we also include labor market controls $\left(Z_{i}\right)$ such as a dummy for public sector employment, job tenure in years, and its squared term.

To deal with the triple selection into emigration, illegality, and return decisions, we model three interrelated decisions through reduced form equations: (1) the probability of emigration, (2) the probability of undocumented migration, and (3) the probability of return migration. Our total sample consists of 14,897 observations: 12,804 individuals are non-migrants, 1,346 are return migrants (out of whom 481 had an undocumented migration), and 747 individuals are current migrants. ${ }^{13}$

First, we denote the probability of temporary migration as $M_{i}$. An individual decides to migrate when the unobservable latent variable $M^{*}$ capturing the individual gains from migration is positive, while an individual decides to stay if the gains from migration are negative. For identification of equation (2), we use the inflation adjusted oil prices $\left(\mathrm{Oil}_{t}\right)$ for each individual at the age of 25, the average age of migration. To obtain an exogenous source of variation in the probability of migration, we follow the same identification strategy proposed by Wahba and Zenou (2012), Wahba (2015), and Elmallakh and Wahba (2021b). The rationale behind using historic oil prices as a predictor of the migration probability is that other Arab countries constitute the most important destination for Egyptian migrants, where oil prices played a crucial role in driving the demand for foreign labor both directly in the Gulf countries or indirectly, in other non-oil-producing Arab countries. ${ }^{14}$ When

\footnotetext{
13 It is important to note that this is the total sample we use to estimate our CMP model. When we have partially observed dependent variables, the CMP model, as a standard selection model, includes all observations where at least one of the dependent variables is observed. This is done either assuming that the missingness pattern of the data is exogeneous or endogenous-as in our model-relying on proper identification to model these various selection processes. In our analysis, the samples used for estimation in the different equations of the CMP model do not necessarily overlap. For instance, in the structural equation, our sample includes only individuals with non-missing wage information, while this does not need to apply across the other reduced form equations. In the regression tables, we report the samples used for the estimation of each equation.

${ }^{14}$ Ninety-eight percent of return migrants in our estimation sample went to other Arab countries.
} 
estimating equation (2), the sample includes return migrants, current migrants, and non-migrants. 15

$$
M_{i}=\alpha_{0}+\alpha_{1} X_{i}+\alpha_{2} \text { Oil }_{t}+\varepsilon_{i} \quad M_{i}=\left\{\begin{array}{l}
1 \text { if } M^{*}>0 \\
0 \text { if } M^{*} \leq 0
\end{array}\right.
$$

Second, we denote the probability of undocumented migration by $I_{i}$. This is only observed for the subsample of migrants. Therefore, the sample used to estimate equation (3) only includes return and current migrants. A migrant decides to undertake an illegal migration if the value of the unobservable latent variable $I^{*}$ is positive and it captures the perceived gains from undocumented migration. By contrast, a migrant decides to undertake a legal migration if the value of the latent variable $I^{*}$ is negative. In equation (3), we use the diplomatic exchange ( $\operatorname{Dip}_{c, t}$ ) between Egypt and the countries of destination of Egyptian migrants at the time of migration for identification. The diplomatic exchange variable is both country and year specific, and is derived from the Correlates of War Diplomatic exchange dataset. ${ }^{16}$ Our diplomatic exchange variable captures diplomatic representation at the level of Chargé d'Affaires, minister, and ambassador between Egypt and all members of the Correlates of War interstate system, every 5 years for our period of analysis. ${ }^{17}$ The identifying assumption is that exogenous shocks to the bilateral diplomatic relations between Egypt and the countries of destination of Egyptian migrants constitute a strong predictor of undocumented migration.

$$
\left(I_{i} \mid M_{i}=1\right)=\beta_{0}+\beta_{1} X_{i}+\beta_{2} \operatorname{Dip}_{c, t}+\omega_{i} \quad I_{i}=\left\{\begin{array}{l}
1 \text { if } I^{*}>0 \\
0 \text { if } I^{*} \leq 0
\end{array}\right.
$$

Third, we also account for return migration; i.e., not every migrant returns to Egypt within our window of observation. The probability of return migration is denoted by $R_{i}$. This is only observed for the subsample of migrants (current and return migrants). A migrant decides to return to Egypt if the value of the unobservable latent variable $R^{*}$ is positive and it captures the gains from return migration. By contrast, a migrant decides to stay abroad if the value of the latent variable $R^{*}$ is negative. For identification of equation (4), we use the number of active armed conflicts ( Conflict $_{c, t}$ ) in the countries of destination of Egyptian migrants at the time of migration (for current migrants) and at the time of return migration (for return migrants). We rely on this instrument for the identification of the return migration equation since most Egyptians migrate to other Arab countries and since, in recent years, many of these countries experienced a series of conflicts. To name just a few, these conflicts include

\footnotetext{
15 Elmallakh and Wahba (2021a) also report descriptive statistics on current migrants and return migrants. Return migrants are found to be older than current migrants and are more likely to be married. We also find that current migrants are on average more educated compared to return migrants. For instance, the share of individuals with secondary education or above secondary education is 15 percentage points higher among current migrants relative to return migrants.

16 Information on diplomatic representation from the Correlates of War Diplomatic exchange dataset is available every 5 years between 1950 and 2005. When matching diplomatic representation with the year of migration from the ELMPS 2012, we use the closest year prior to the year of migration. For example, if an individual migrated in 1973, we use diplomatic representation in the year 1970.

17 See the Data Appendix 2.1 for a description of the Correlates of War Diplomatic Exchange Dataset.
} 
the Iran-Iraq war between 1980 and 1988, the 1986 South Yemen civil war, the Gulf war in 1990 and 1991, and the Iraq war in 2003 following the US invasion. The identifying assumption is that conflict occurrence in these countries constitutes a strong predictor of return migration. The number of active armed conflicts is both country and year specific and comes from the Monadic Conflict Onset and Incidence dataset of the Uppsala Conflict Data Project (UCDP). ${ }^{18}$

$$
R_{i}=\gamma_{0}+\gamma_{1} X_{i}+\gamma_{2} \text { Conflict }_{c, t}+\tau_{i} \quad R_{i}=\left\{\begin{array}{l}
1 \text { if } R^{*}>0 \\
0 \text { if } R^{*} \leq 0
\end{array}\right.
$$

When estimating the reduced form equation (2), equation (3), and equation (4), our regressions include the same vector of individual controls $\left(X_{i}\right)$. In these equations, $X_{i}$ additionally includes decades of migration dummies. In our CMP model, the error terms $v, \varepsilon, \omega$, and $\tau$ are allowed to be correlated through a multidimensional distribution.

\subsection{Discussion on the exclusion restrictions}

In this section, we discuss issues pertaining to the validity of our empirical model presented in Section 4.1. First, in Section 4.2.1, we discuss the exclusion restriction of oil prices and present evidence supporting the orthogonality of oil prices to both illegality and return decisions. Second, in Section 4.2.2, we discuss the evolution of Egypt's diplomatic relations with other Arab countries and provide evidence that migration is not influenced by the bilateral relationship of countries. Third, in Section 4.2.3, we discuss concerns related to the exclusion restriction of conflict occurrence and how we address them empirically.

\subsubsection{The exclusion restriction of oil prices}

The exclusion restriction of oil prices is that oil prices affect wages in Egypt only through temporary migration decision. Since Egypt is a non-dependent oil economy, the exclusion restriction holds if oil prices at the age of 25 are not correlated with employment and wages in Egypt. To provide support to our identifying assumption, in Fig. 1 in panel a, we present oil prices against key aggregate economic indicators in Egypt including GDP annual growth rate, male labor force participation rate, male employment in agriculture ( $\%$ of total male employment), male employment in industry ( $\%$ of total male employment), and male employment in services (\% of total male employment). ${ }^{19}$ The top panel in Fig. 1 provides support to our exclusion restriction since key economic and labor market indicators in Egypt are unaffected by oil prices' fluctuations.

\footnotetext{
18 See the Data Appendix 2.2 for a description of the Monadic Conflict Onset and Incidence dataset from the Uppsala Conflict Data Project (UCDP).

19 Labor Force participation rate, employment in agriculture, industry, and services come from Key indicators of the Labor Market Database of the International Labor Organization. GDP growth rates come from the World Bank National accounts data files. The choice of the time period is dictated by data availability.
} 


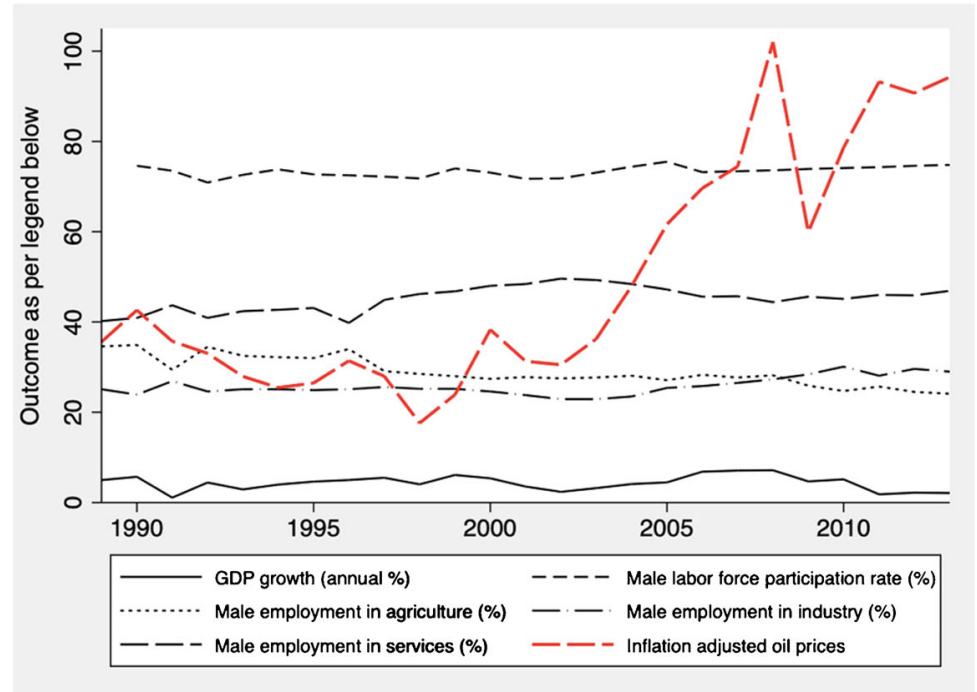

(a) Oil prices versus agregrate indicators

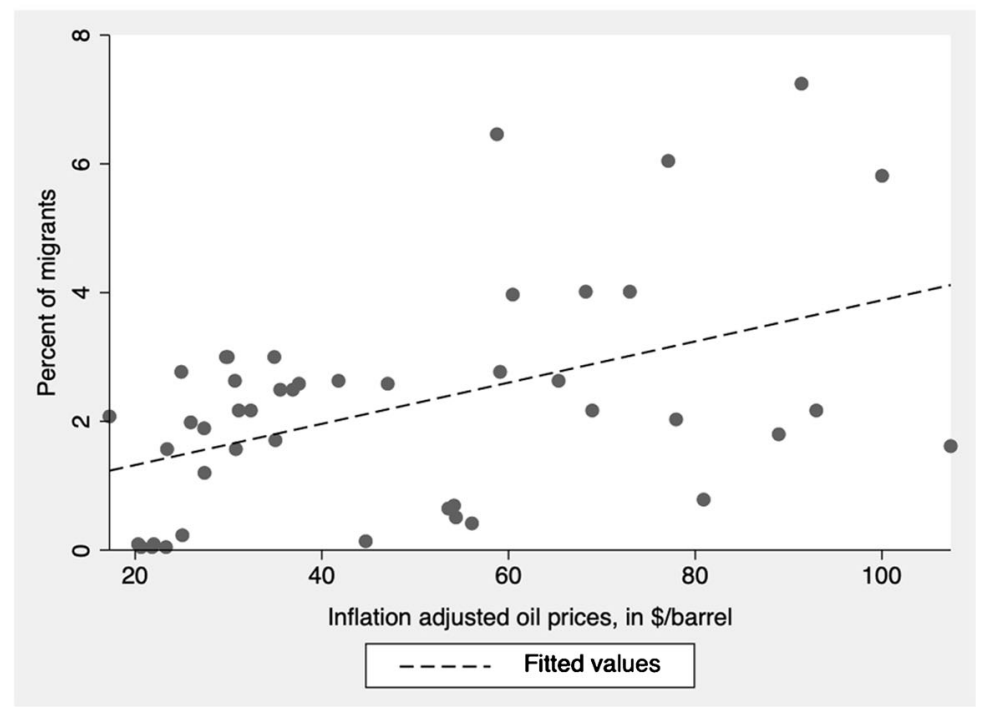

(b) Oil prices and migration

Fig. 1 Oil prices, aggregate indicators, and migration flows. Oil prices are inflation adjusted and expressed in \$ per barrel. In panel a, labor force participation rate, employment in agriculture, industry, and services are from the International Labor Organization, Key indicators of the Labor Market Database. GDP growth rates are from the World Bank National accounts data files. Panel b presents a scatter plot of the inflation adjusted oil prices (horizontal X-axis) and the share of migrants per year (vertical Y-axis). The share of migrants is derived from the ELMPS 2012 using information on current and return migration and the year of migration and is computed as the number of migrants in a specific year divided by the number total migrants. The dashed line represents a fitted regression line 
In Fig. 1 in panel b, we present a scatter plot featuring the evolution of the inflation adjusted oil prices and migration patterns from the 1960 s to 2010 . The share of migrants is derived from the ELMPS (2012), using information on both current and return migrants, and on the year of migration. The fitted regression line shows a positive correlation between oil prices and the share of migrants. While panel a provides support to the exclusion restriction of oil prices, panel b shows that oil prices constitute indeed a strong predictor of migration decisions.

A potential threat to identification would be the non-orthogonality of oil prices (1) to legal status of migrants, or (2) to return decisions. We discuss these two issues and present evidence supporting the orthogonality of oil prices to these two decisions. In Fig. 2 in panel a, we present the yearly evolution of oil prices and the percent of undocumented migrants derived from the ELMPS. ${ }^{20}$ If oil price shocks directly affect the probability of illegal migration, this would suggest that when oil prices are high, Egyptian migrants might be more frequently willing to emigrate irregularly since it would be more profitable. Panel a in Fig. 2 shows that the two series-oil prices and the share of undocumented migrants-do not follow the same trend. Indeed, this figure shows several episodes of spikes in oil prices, during which irregular migration remained low. Conversely, irregular migration was particularly high in the late 1960s and early 1970 s - a period with relatively low oil prices. We further corroborate this evidence in panel $b$, where we present a scatter plot on the relationship between oil prices and the share of undocumented migrants from the 1960s to 2010. Panel b in Fig. 2 additionally confirms the orthogonality of oil prices with respect to irregular migration flows. Indeed, there does not seem to be any correlation between oil prices and illegality. We find a correlation coefficient of 0.042 with an associated $P$-value of 0.787 .

For the validity of the identification strategy, we additionally discuss the issue of non-orthogonality of oil prices to return migration decisions. A potential concern would be if individuals who migrate with high oil price may also be more likely to return when oil prices go down. In Fig. 3 in panel a, we present the evolution of oil prices against the evolution of both the share of return migrants and the share of migrants from the late 1960 s to 2012 . While we find that the share of migrants closely mimics oil price fluctuations, we do not find a clear association between oil price shocks and the share of return migrants. While return migration seems to have peaked in the late 1980s following the drop in oil prices, it likewise peaked again in the late 2000 s even though oil registered particularly high price levels. The direction of the association between oil prices and return migration is therefore not a priori clear. In panel $b$, we further present a scatter plot on the relationship between oil prices and the share of return migrants. The fitted regression line shows that oil prices are indeed uncorrelated with return migration flows. We find a correlation coefficient of 0.118 with a $P$-value 0.476 . The evidence provided in Fig. 2 and Fig. 3

\footnotetext{
20 The percent of undocumented migrants is computed as the number of undocumented migrants in a specific year to the total number of migrants in the same year, using information on current, return migrants, and the year of migration.
} 


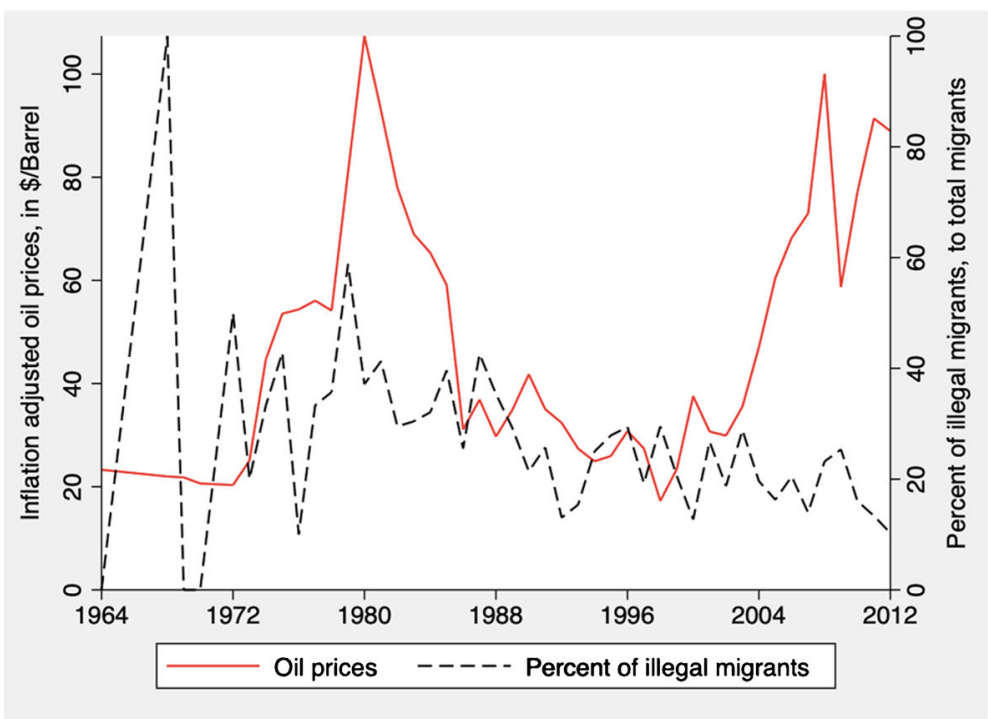

(a) Evolution of oil prices and illegality

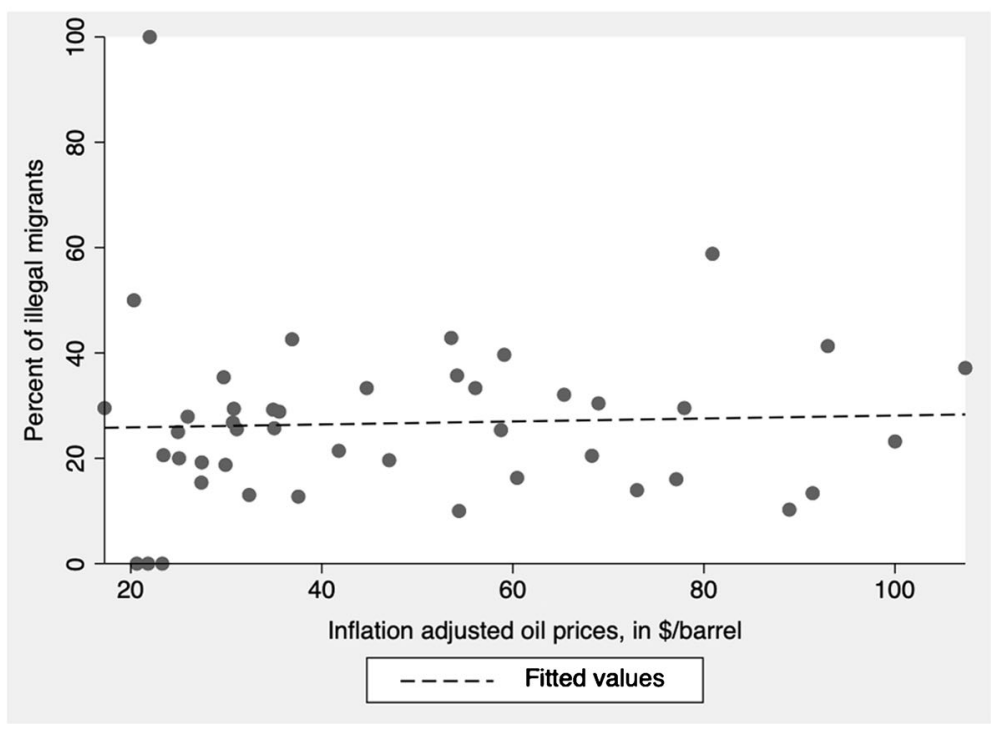

(b) Relationship between oil prices and illegality

Fig. 2 Oil prices and illegal migration flows. Oil prices are inflation adjusted and expressed in \$ per barrel. The percent of undocumented migrants is derived from the ELMPS 2012, using information on current and return migrants, and the year of migration and is computed as the number of undocumented migrants in a specific year to the total number of migrants in the same year. Panel a presents the yearly evolution of oil prices and the percent of undocumented migrants. Panel b presents a scatter plot of the inflation adjusted oil prices (horizontal X-axis) and the percent of undocumented migrants per year (vertical Y-axis). The dashed line represents a fitted regression line 
therefore shows that oil prices are indeed orthogonal to both illegality and return decisions.

\subsubsection{The exclusion restriction of diplomatic exchange}

Before discussing the exclusion restriction of our diplomatic exchange variable, we also highlight the evolution of Egypt's diplomatic relations and the variability of diplomatic representation for the validity of our identification strategy.

In Table 14 in the Appendix, we report the share of countries with diplomatic representation in Egypt by year. ${ }^{21}$ Indeed, our diplomatic representation variable shows significant variability over time. The first important decrease in diplomatic representation between Egypt and migrants' destination countries-predominantly other Arab countries - is observed in the 1960s. Nasser, the Egyptian president at the time who was elected in 1956, was becoming increasingly popular in the Arab world as the leader for pan-Arabism which culminated in the United Arab Republic with Syria in the late 1950s and early 1960s. As Nasser's ideology gained support in various Arab countries, disagreements emerged between Egypt and Arab monarchies, importantly, Saudi Arabia, for which pan-Arabism posed a real threat to its stability. While Egypt's pan-Arab ideology resonated with a number of Arab countries, it also led to conflicting dynamics with the monarchies (Mann 2012). These dynamics explain the observed decrease in diplomatic representation in the 1960s and early 1970s.

The second sharp decrease in diplomatic representation is observed in the 1980s. This episode coincides with Egypt's signing of the Camp David Agreement with Israel in 1978, followed by the conclusion of the peace treaty between the two countries in 1979. Following these events, the perception of the Arab world towards Egypt changed in particular, since for decades Egypt was presumed to stand for Arab interests. In November 1978, in a summit meeting held in Baghdad, a consensus among Arab countries was reached to impose economic and political sanctions on Egypt (Lavy 1984; Sullivan 1999). Egypt was subsequently suspended from the Arab League from 1979 until 1989. Evidently, this political and economic embargo negatively affected the bilateral relations between Egypt and other Arab countries, as reflected in the sharp drop in diplomatic representation in the 1980s. As shown in the descriptive statistics in Table 13 in the Appendix, these events coincide with greater undocumented migration in the 1980s.

A potential concern would be if migration is influenced by the bilateral relationship of countries, i.e., if individuals consider the bilateral diplomatic relations between Egypt and alternative countries of destination when taking their migration decisions. To dispel this concern, in Fig. 4 in the Appendix, we present the share of migrants who migrated to countries without diplomatic representation and to

21 We focus on the subset of destination countries in our sample. 


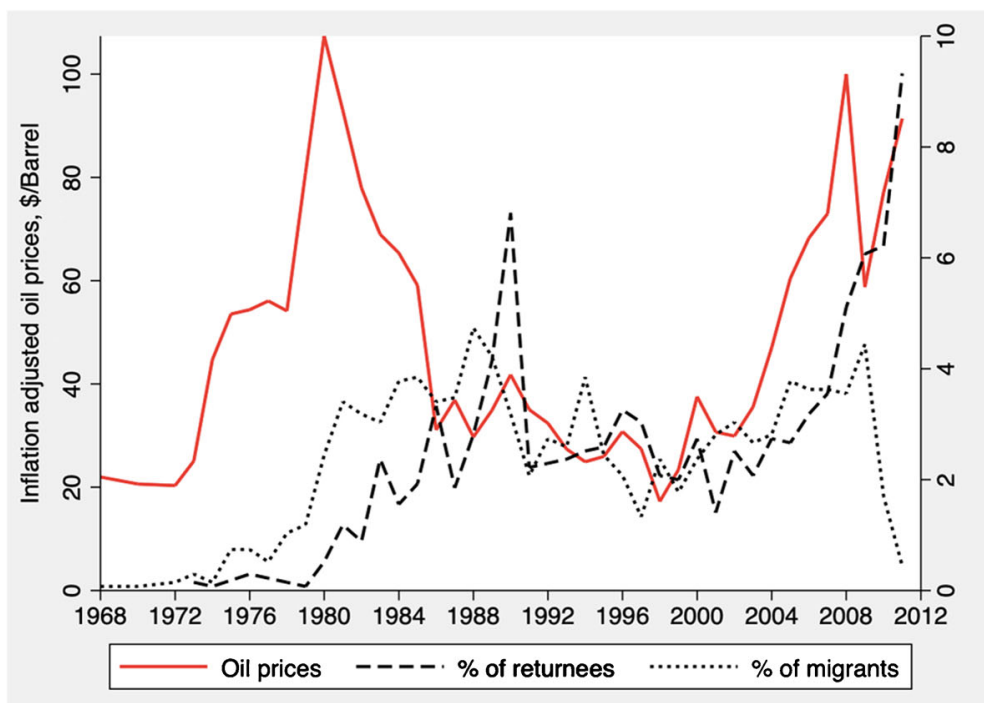

(a) Evolution of oil prices, emigration and return migration

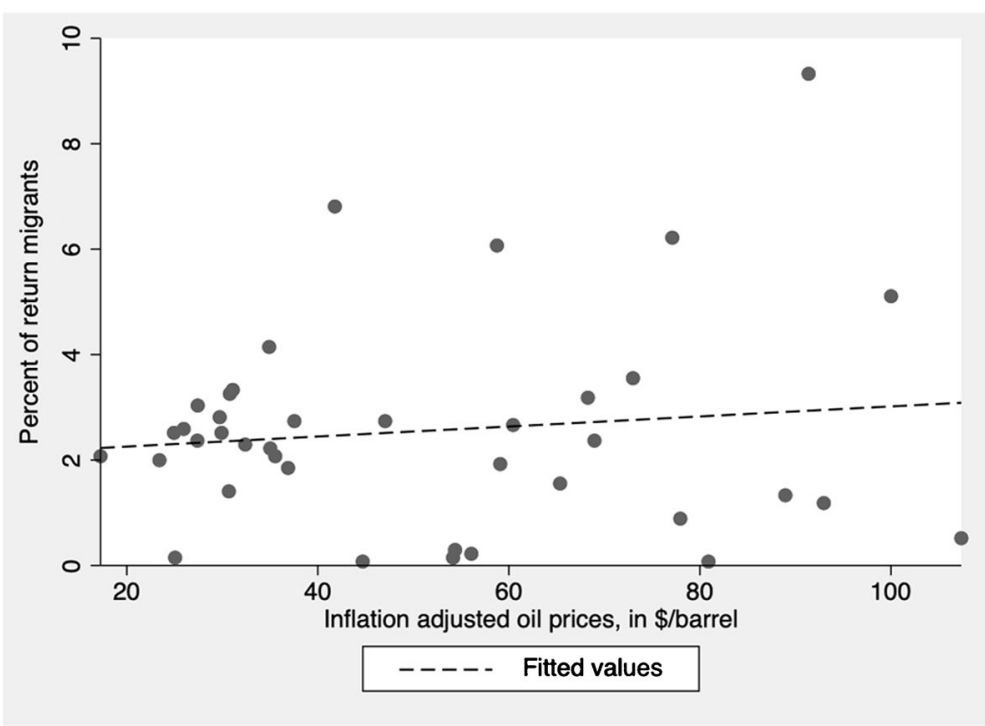

(b) Relationship between oil prices and return migration

Fig. 3 Oil prices and return migration flows. Oil prices are inflation adjusted and expressed in \$ per barrel. The percent of return migrants is derived from the ELMPS 2012, using information on return migration and the year of final return. The percent of return migrants is computed as the share of return migrants in a specific year to the total number of return migrants. In panel a, the percent of migrants is derived from the ELMPS 2012, using information on the year of first migration among return migrants. Panel b presents a scatter plot of the inflation adjusted oil prices (horizontal X-axis) and the share of return migrants per year (vertical Y-axis). The dashed line represents a fitted regression line 
countries with diplomatic representation in Egypt by year of migration. ${ }^{22}$ Figure 4 shows that migrants do not consistently consider diplomatic representation when undertaking their migration decisions. For instance, in the years between 1968 and 1980, all migrants went to countries with no diplomatic representation in Egypt. On the other hand, in every single year between 1981 and 1990, migrants predominantly chose to migrate to countries without diplomatic representation in Egypt. Between 1992 and 1995, the majority of migrants chose destinations with diplomatic representation, while a non-negligible share of migrants still migrated to countries with no diplomatic representation. On the other hand, from 1996 onwards, migration was destined to countries with diplomatic exchange but it is important to note that this is a period with little variability in diplomatic representation, as shown in Table 14 in the Appendix.

Overall, these patterns do not show a clear-cut relationship between diplomatic representation and migration, whereby individuals decide to migrate mostly to countries with diplomatic representation. In fact, Fig. 4 suggests that diplomatic representation does not predict migration decisions. Elmallakh and Wahba (2021a) further investigate the relationship between diplomatic exchange and migration flows. They present a scatter plot on the relationship between diplomatic representation and the share of migrants. Even though the scatter plot is derived from data of limited sample size, the analysis confirms that migration is not directly influenced by diplomatic exchange, in line with Fig. 4.

\subsubsection{The exclusion restriction of conflicts}

In this section, we discuss two concerns related to the exclusion restriction of conflicts in the return migration equation and how we address them empirically in Section 6. The first one is that our instrument would only predict forced return migration due to armed conflicts and not planned return migration. To address this challenge, in Section 6, we also control for labor market outcomes at destination to account for planned return migration. We augment our return migration equation (4) with the unemployment rate at destination at the time of return migration (for return migrants) and at the time of the survey in 2012 (for current migrants). This allows us to account for both forced return migration and planned return.

While conflict occurrence in host countries constitutes a strong predictor of return migration, an empirical concern would be if conflicts might have consequences on the Egyptian economy through, for instance, changes in trade flows, foreign direct investments, or remittances. To address this concern, we additionally rely on data from the World Bank Development Indicators in order to control for FDI (\% of GDP), remittances (\% of GDP), and the exports and imports of goods and services (\% of GDP) in Egypt in equation (4). We show in Section 6 that our results are robust to these two checks, which provides support to the exclusion restriction of conflict occurrence.

\footnotetext{
22 The share of migrants, in a particular year, is computed at the share of total migrants (return and current migrants) that went to countries with zero diplomatic representation in Egypt and the share of total migrants (return and current migrants) that went to countries with diplomatic representation in Egypt.
} 


\section{Empirical findings}

\subsection{Does the legal status of migrants matter upon return?}

\subsubsection{Hourly wages upon return}

In Table 4, we depart from simple OLS regressions to estimate the effect of return migration on wages in 2012 upon return. We are interested in examining whether the legal status of migrants has a differential effect on their wage premium upon return. In column (1), we focus on the full sample of non-migrants and returnees. In column (2), we focus on the subsample of documented migrants compared to nonmigrants, and in column (3), we compare undocumented migrants to non-migrants. Without accounting for any of the selection issues presented earlier, Table 4 shows that controlling for individual and job characteristics, return migration is associated with a significant wage premium. However, when we disentangle the effects by legal status, the results show that this positive association between return migration and wages holds only for documented migrants.

Accounting for the triple selection into migration, illegality, and return using a conditional mixed process model, in Table 5, we estimate equation (1a) on the effect of illegality on hourly wages upon return, conditional on return migration. We start by presenting the results from the reduced form equations and then discuss the results from our primary structural equation (1a). First, we find that oil prices are a strong predictor of the probability of migration. In column (1), we find that a one dollar increase in oil prices leads to an increase in the probability of migration by 1.3 percentage points. Diplomatic exchange also plays a crucial role in explaining the legal migrant status. In column (2), we find strong suggestive evidence that negative

Table 4 Estimating the effect of return migration on hourly wages

\begin{tabular}{|c|c|c|c|}
\hline & $\begin{array}{l}\text { Returnees } \\
\text { versus non-migrants } \\
\text { (1) }\end{array}$ & $\begin{array}{l}\text { Documented migrants } \\
\text { versus non-migrants } \\
\text { (2) }\end{array}$ & $\begin{array}{l}\text { Undocumented migrants } \\
\text { versus non-migrants } \\
\text { (3) }\end{array}$ \\
\hline & Log of hourly wage & Log of hourly wage & Log of hourly wage \\
\hline Return migrant & $\begin{array}{l}0.059 * * \\
(0.027)\end{array}$ & $\begin{array}{l}0.070 * * \\
(0.033)\end{array}$ & $\begin{array}{l}0.038 \\
(0.041)\end{array}$ \\
\hline Observations & 8,156 & 7,874 & 7,719 \\
\hline$R$-squared & 0.127 & 0.130 & 0.125 \\
\hline Individual controls & Yes & Yes & Yes \\
\hline Job characteristics & Yes & Yes & Yes \\
\hline
\end{tabular}

Robust standard errors in parentheses. $* * * p<0.01 ; * * p<0.05 ; * p<0.1$

Coefficient estimates are reported using OLS regressions. Individual controls include age and its squared term, educational attainment dummies (no educational degree, primary or preparatory education, secondary education, and above secondary education), and a dummy variable for rural residence. Job characteristics include sector of employment, a dummy for having a work contract, and job tenure in years 
Table 5 Estimating the effect of migrants' legal status on hourly wages after return, conditional on return migration

\begin{tabular}{|c|c|c|c|c|}
\hline & (1) & (2) & (3) & (4) \\
\hline & Migrate & Illegal & Return & $\begin{array}{l}\text { Log of } \\
\text { hourly wage }\end{array}$ \\
\hline \multirow[t]{2}{*}{ Age } & $0.012 * * *$ & $-0.077 * *$ & $-0.014 * *$ & -0.044 \\
\hline & $(0.001)$ & $(0.034)$ & $(0.006)$ & $(0.036)$ \\
\hline \multirow[t]{2}{*}{ Age squared } & $-0.000 * * *$ & $0.001 * *$ & $0.000 * * *$ & 0.001 \\
\hline & $(0.000)$ & $(0.000)$ & $(0.000)$ & $(0.000)$ \\
\hline \multirow[t]{2}{*}{ No education } & $0.019 * * *$ & $0.497 * * *$ & -0.030 & $-0.398 * * *$ \\
\hline & $(0.004)$ & $(0.120)$ & $(0.021)$ & $(0.106)$ \\
\hline \multirow[t]{2}{*}{ Primary or preparatory } & $0.032 * * *$ & $0.469 * * *$ & $0.049 * *$ & $-0.447 * * *$ \\
\hline & $(0.004)$ & $(0.129)$ & $(0.022)$ & $(0.103)$ \\
\hline \multirow[t]{2}{*}{ Secondary } & $0.017 * * *$ & $0.401 * * *$ & $0.033^{*}$ & $-0.140^{*}$ \\
\hline & $(0.003)$ & $(0.105)$ & $(0.017)$ & $(0.078)$ \\
\hline \multirow[t]{2}{*}{ Rural } & $0.009 * * *$ & $0.254 * * *$ & 0.009 & -0.020 \\
\hline & $(0.003)$ & $(0.084)$ & $(0.015)$ & $(0.063)$ \\
\hline \multirow[t]{2}{*}{ Oil prices } & $0.013 * * *$ & & & \\
\hline & $(0.000)$ & & & \\
\hline \multirow[t]{2}{*}{ Diplomatic exchange } & & $-0.227 * *$ & & \\
\hline & & $(0.102)$ & & \\
\hline \multirow[t]{2}{*}{ Conflict } & & & $0.047 * * *$ & \\
\hline & & & $(0.013)$ & \\
\hline \multirow[t]{2}{*}{ Illegal status } & & & & $-0.596 * * *$ \\
\hline & & & & $(0.151)$ \\
\hline Observations & 14,879 & 1,955 & 2,071 & 718 \\
\hline Parental controls & Yes & Yes & Yes & Yes \\
\hline Decades of migration dummies & Yes & Yes & Yes & No \\
\hline Labor market controls in Egypt & No & No & No & Yes \\
\hline \multicolumn{5}{|c|}{ Predicted log wage: Illegal mig. $=1.242 ;$ Legal mig. $=1.838$} \\
\hline
\end{tabular}

Robust standard errors in parentheses. $* * * p<0.01 ; * * p<0.05 ; * p<0.1$

Equation 1 is the probability of temporary migration. Equation 2 is the probability of undocumented migration. Equation 3 is the probability of return migration. Equation 4 models the logarithm of hourly wages upon return. For identification of equation (1), we use the inflation adjusted historical oil prices (in US dollars). For identification of equation (2), we use the diplomatic exchange, which is the diplomatic representation of each country of destination of Egyptian migrants in Egypt at time of migration. It is a dummy variable equal to zero if there is no evidence of diplomatic exchange and is equal to one if there is evidence of diplomatic exchange at the level of chargé d'affaires, minister, ambassador, or other. For identification of equation (3), we use the number of active armed conflicts that is both country and year specific from the Uppsala Conflict Data Project (UCDP). Equation (4) estimates the effect of illegality on the logarithm of hourly wages, conditional on return migration. The predicted logarithm of hourly wages for migrants by legal status is reported in the last row 
shocks to the bilateral relations between Egypt and the countries of destination of Egyptian migrants, at the time of migration, drive illegal migration to the destination countries. Indeed, we find that the lack of diplomatic representation of countries of destination in Egypt leads to an increase in the probability of illegal migration by 23 percentage points. As for identification of the return migration, in column (3), we find that an additional active armed conflict that occurs in the destination country at the time of return migration (for return migrants) or at the time of migration (for current migrants) increases the probability of return migration by 5 percentage points. Correcting for this triple selection into migration, illegality, and return, in column (4), we find that undocumented migrants witness a wage penalty compared to legal migrants upon return to Egypt.

To assess how undocumented migrants fare with respect to non-migrants in terms of wages upon return, in Table 6, we estimate equation (1b) unconditional on return migration. Therefore, in column (4), our sample includes non-migrants in addition to return migrants (documented and undocumented). Indeed, we find that undocumented migrants witness a wage penalty relative to non-migrants, while only documented migrants witness a wage premium. To compute the wage penalty associated with undocumented migration, we rely on the predicted logarithm of hourly wages for non-migrants, illegal, and legal migrants in the last row of Table 6. The difference in logarithms approximate the percentage change in hourly wages. We find that undocumented migration yields to a $19 \%$ wage penalty with respect to nonmigrants. On the other hand, we find that documented migration leads to a positive wage premium of $28 \%$. The estimates therefore suggest that the wage penalty of undocumented migrants relative to documented migrants is estimated to be around $47 \% .^{23}$

\subsubsection{Occupations, labor supply, and monthly wages upon return}

While we are primarily interested in the impact of illegality on hourly wages upon return, in this section, we expand our analysis to other outcomes such as occupations, labor supply, and monthly wages upon return. In Tables 7 and 8, we examine the effect of migrants' legal status on occupations and labor supply upon return, respectively. We estimate equation (1b), unconditional on return migration. In Table 7, our dependent variable is occupational ranking. Occupations are split into 9 distinct categories according to the ISCO-88 one digit classification. They are ranked from 1 to 9 according to the amount of human capital needed to be employed in each occupation following Sicherman and Galor (1990) and Carletto and Kilic (2011). According to

\footnotetext{
23 Throughout our analysis, to compute the differences in outcomes between non-migrants, documented migrants, and undocumented migrants, we rely on the predicted values of our dependent variable from our structural equation (1a) and equation (1b). For example, in Table 6, the wage penalty of undocumented migrants with respect to documented migrants is equal to $1.515-1.329=0.186(19 \%)$, while the wage premium witnessed by documented migrants with respect to non-migrants is equal to $1.794-1.515=$ $0.279(28 \%)$. Therefore, the total wage penalty of undocumented migrants with respect to documented migrants is equal to $19 \%+28 \%=47 \%$.
} 
Table 6 Estimating the effect of migrants' legal status on hourly wages after return, unconditional on return migration

\begin{tabular}{|c|c|c|c|c|}
\hline & $\begin{array}{l}\text { (1) } \\
\text { Migrate }\end{array}$ & $\begin{array}{l}(2) \\
\text { Illegal }\end{array}$ & $\begin{array}{l}\text { (3) } \\
\text { Return }\end{array}$ & $\begin{array}{l}(4) \\
\text { Log of } \\
\text { hourly wage }\end{array}$ \\
\hline Age & $\begin{array}{l}0.012 * * * \\
(0.001)\end{array}$ & $\begin{array}{l}-0.074 * * \\
(0.034)\end{array}$ & $\begin{array}{l}-0.014 * * \\
(0.006)\end{array}$ & $\begin{array}{l}-0.001 \\
(0.005)\end{array}$ \\
\hline Age squared & $\begin{array}{l}-0.000 * * * \\
(0.000)\end{array}$ & $\begin{array}{l}0.001 * * \\
(0.000)\end{array}$ & $\begin{array}{l}0.000 * * * \\
(0.000)\end{array}$ & $\begin{array}{l}0.000 * * \\
(0.000)\end{array}$ \\
\hline No education & $\begin{array}{l}0.019 * * * \\
(0.004)\end{array}$ & $\begin{array}{l}0.485 * * * \\
(0.117)\end{array}$ & $\begin{array}{l}-0.030 \\
(0.021)\end{array}$ & $\begin{array}{l}-0.445^{* * *} \\
(0.026)\end{array}$ \\
\hline Primary or preparatory & $\begin{array}{l}0.032 * * * \\
(0.004)\end{array}$ & $\begin{array}{l}0.476^{* * *} \\
(0.125)\end{array}$ & $\begin{array}{l}0.049 * * \\
(0.022)\end{array}$ & $\begin{array}{l}-0.419 * * * \\
(0.025)\end{array}$ \\
\hline Secondary & $\begin{array}{l}0.017 * * * \\
(0.003)\end{array}$ & $\begin{array}{l}0.360 * * * \\
(0.101)\end{array}$ & $\begin{array}{l}0.034 * \\
(0.017)\end{array}$ & $\begin{array}{l}-0.285^{* * *} \\
(0.020)\end{array}$ \\
\hline Rural & $\begin{array}{l}0.009 * * * \\
(0.003)\end{array}$ & $\begin{array}{l}0.256^{* * * *} \\
(0.083)\end{array}$ & $\begin{array}{l}0.009 \\
(0.015)\end{array}$ & $\begin{array}{l}-0.028 * \\
(0.016)\end{array}$ \\
\hline Oil prices & $\begin{array}{l}0.013 * * * \\
(0.000)\end{array}$ & & & \\
\hline Diplomatic exchange & & $\begin{array}{l}-0.229 * * \\
(0.102)\end{array}$ & & \\
\hline Conflict & & & $\begin{array}{l}0.047 * * * \\
(0.013)\end{array}$ & \\
\hline Illegal status & & & & $\begin{array}{l}-0.232^{* * *} \\
(0.053)\end{array}$ \\
\hline Legal status & & & & $\begin{array}{l}0.203 * * * \\
(0.044)\end{array}$ \\
\hline Observations & 14,879 & 1,955 & 2,071 & 8,054 \\
\hline Parental controls & Yes & Yes & Yes & Yes \\
\hline Decades of migration dummies & Yes & Yes & Yes & No \\
\hline Labor market controls in Egypt & No & No & No & Yes \\
\hline
\end{tabular}

Robust standard errors in parentheses. *** $p<0.01$; ** $p<0.05 ; * p<0.1$

Equation 1 is the probability of temporary migration. Equation 2 is the probability of undocumented migration. Equation 3 is the probability of return migration. Equation 4 models the logarithm of hourly wages upon return. For identification of equation (1), we use the inflation adjusted historical oil prices (in US dollars). For identification of equation (2), we use the diplomatic exchange, which is the diplomatic representation of each country of destination of Egyptian migrants in Egypt at time of migration. It is a dummy variable equal to zero if there is no evidence of diplomatic exchange and is equal to one if there is evidence of diplomatic exchange at the level of chargé d'affaires, minister, ambassador, or other. For identification of equation (3), we use the number of active armed conflicts that is both country and year specific from the Uppsala Conflict Data Project (UCDP). Equation (4) estimates the effect of illegality on the logarithm of hourly wages, unconditional on return migration. The predicted logarithm of hourly wages for non-migrants, and migrants with legal and illegal status is reported in the last row 
Table 7 Estimating the effect of migrants' legal status on occupations after return, unconditional on return migration

\begin{tabular}{|c|c|c|c|c|}
\hline & $\begin{array}{l}\text { (1) } \\
\text { Migrate }\end{array}$ & $\begin{array}{l}\text { (2) } \\
\text { Illegal }\end{array}$ & $\begin{array}{l}\text { (3) } \\
\text { Return }\end{array}$ & $\begin{array}{l}\text { (4) } \\
\text { Occupation } \\
\text { upon return }\end{array}$ \\
\hline Age & $\begin{array}{l}0.012 * * * \\
(0.001)\end{array}$ & $\begin{array}{l}-0.072 * * \\
(0.034)\end{array}$ & $\begin{array}{l}-0.014 * * \\
(0.006)\end{array}$ & $\begin{array}{l}0.021 \\
(0.015)\end{array}$ \\
\hline Age squared & $\begin{array}{l}-0.000 * * * \\
(0.000)\end{array}$ & $\begin{array}{l}0.001 * \\
(0.000)\end{array}$ & $\begin{array}{l}0.000 * * * \\
(0.000)\end{array}$ & $\begin{array}{l}-0.001 * * * \\
(0.000)\end{array}$ \\
\hline No education & $\begin{array}{l}0.019 * * * \\
(0.004)\end{array}$ & $\begin{array}{l}0.492 * * * \\
(0.121)\end{array}$ & $\begin{array}{l}-0.029 \\
(0.021)\end{array}$ & $\begin{array}{l}2.970 * * * \\
(0.073)\end{array}$ \\
\hline Primary or preparatory & $\begin{array}{l}0.032 * * * \\
(0.004)\end{array}$ & $\begin{array}{l}0.463 * * * \\
(0.130)\end{array}$ & $\begin{array}{l}0.050^{* *} \\
(0.022)\end{array}$ & $\begin{array}{l}2.837 * * * \\
(0.071)\end{array}$ \\
\hline Secondary & $\begin{array}{l}0.017 * * * \\
(0.003)\end{array}$ & $\begin{array}{l}0.416 * * * \\
(0.107)\end{array}$ & $\begin{array}{l}0.033 * \\
(0.017)\end{array}$ & $\begin{array}{l}2.102 * * * \\
(0.059)\end{array}$ \\
\hline Rural & $\begin{array}{l}0.009 * * * \\
(0.003)\end{array}$ & $\begin{array}{l}0.260 * * * \\
(0.085)\end{array}$ & $\begin{array}{l}0.008 \\
(0.015)\end{array}$ & $\begin{array}{l}0.099 * * \\
(0.040)\end{array}$ \\
\hline Oil prices & $\begin{array}{l}0.013 * * * \\
(0.000)\end{array}$ & & & \\
\hline Diplomatic exchange & & $\begin{array}{l}-0.267 * * * \\
(0.103)\end{array}$ & & \\
\hline Conflict & & & $\begin{array}{l}0.046^{* * * *} \\
(0.013)\end{array}$ & \\
\hline Illegal status & & & & $\begin{array}{l}-0.121 \\
(0.253)\end{array}$ \\
\hline Legal status & & & & $\begin{array}{l}0.189 \\
(0.189)\end{array}$ \\
\hline Observations & 14,879 & 1,955 & 2,071 & 10,764 \\
\hline Parental controls & Yes & Yes & Yes & Yes \\
\hline Decades of migration dummies & Yes & Yes & Yes & No \\
\hline Labor market controls in Egypt & No & No & No & Yes \\
\hline \multicolumn{5}{|c|}{ Predicted occupation: Non-mig.: 5.394; illegal mig. $=5.255$; legal mig. $=5.306$} \\
\hline
\end{tabular}

Robust standard errors in parentheses. *** $p<0.01$; ** $p<0.05$; * $p<0.1$

Equation 1 is the probability of temporary migration. Equation 2 is the probability of undocumented migration. Equation 3 is the probability of return migration. Equation 4 models the occupational ranking upon return. For identification of equation (1), we use the inflation adjusted historical oil prices (in US dollars). For identification of equation (2), we use the diplomatic exchange, which is the diplomatic representation of each country of destination of Egyptian migrants in Egypt at time of migration. It is a dummy variable equal to zero if there is no evidence of diplomatic exchange and is equal to one if there is evidence of diplomatic exchange at the level of chargé d'affaires, minister, ambassador, or other. For identification of equation (3), we use the number of active armed conflicts that is both country and year specific from the Uppsala Conflict Data Project (UCDP). Equation (4) estimates the effect of illegality on occupational ranking upon return, unconditional on return migration. Occupational ranking is computed according to the ISCO-88 one digit classification. The greater the ranking, the higher is the occupation classified in the occupational ladder. The predicted occupational ranking for non-migrants, and migrants with legal and illegal status is reported in the last row 
Table 8 Estimating the effect of migrants' legal status on labor supply, unconditional on return migration

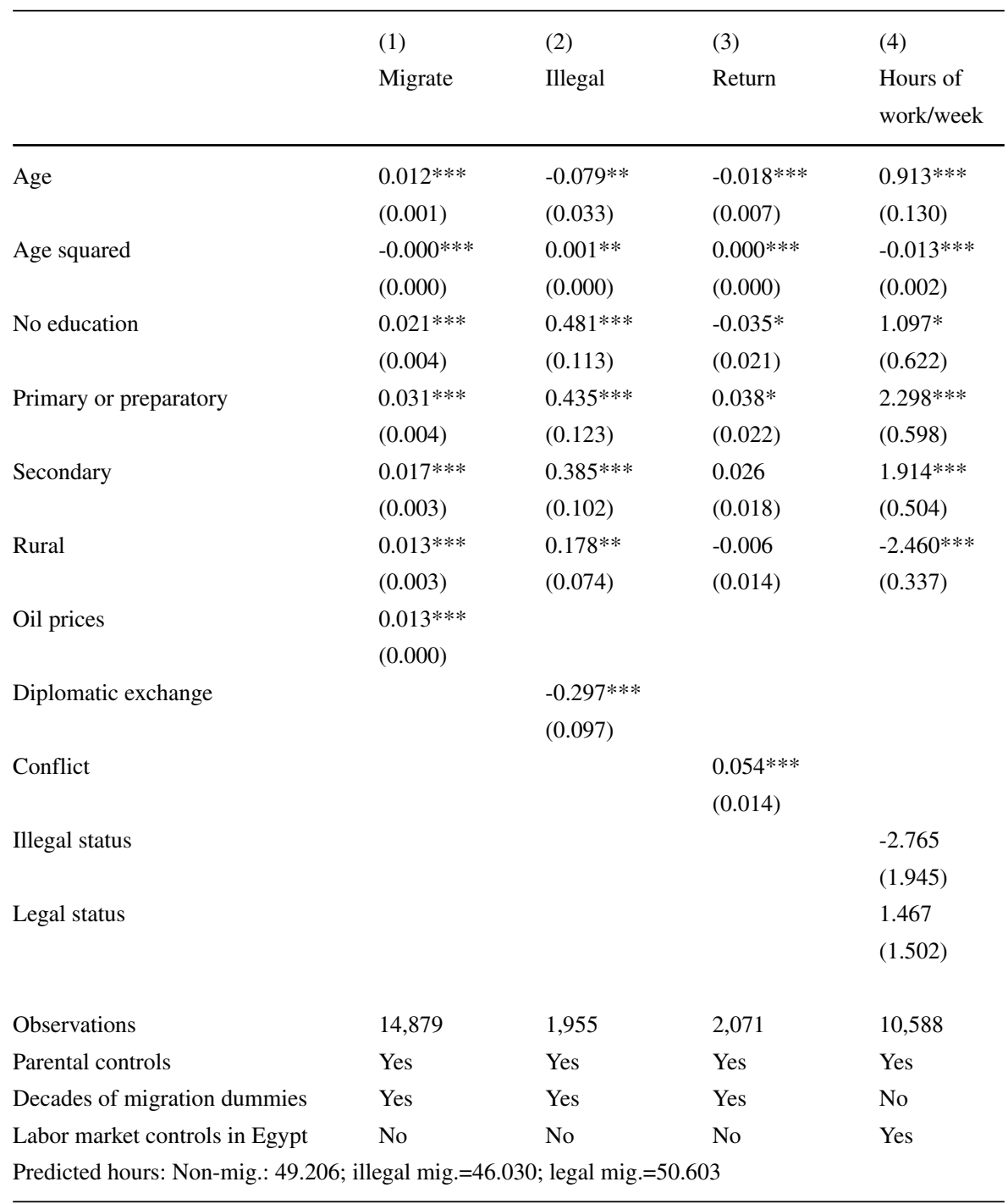

Robust standard errors in parentheses. *** $p<0.01$; ** $p<0.05 ; * p<0.1$

Equation 1 is the probability of temporary migration. Equation 2 is the probability of undocumented migration. Equation 3 is the probability of return migration. Equation 4 models labor supply upon return. For identification of equation (1), we use the inflation adjusted historical oil prices (in US dollars). For identification of equation (2), we use the diplomatic exchange, which is the diplomatic representation of each country of destination of Egyptian migrants in Egypt at time of migration. It is a dummy variable equal to zero if there is no evidence of diplomatic exchange and is equal to one if there is evidence of diplomatic exchange at the level of chargé d'affaires, minister, ambassador, or other. For identification of equation (3), we use the number of active armed conflicts that is both country and year specific from the Uppsala Conflict Data Project (UCDP). Equation (4) estimates the effect of illegality of the number of hours of work/week, unconditional on return migration. The predicted number of hours of work/week for non-migrants, and migrants with legal and illegal status is reported in the last row 
this ranking, our dependent variable takes the value 1 for the lowest-ranked occupation and 9 for the highest-ranked occupation. ${ }^{24}$ In Table 8, our independent variable of interest is the number of hours of work/week. Accounting for the triple selection into emigration, legal status, and return, Table 7 shows that migrants' legal status does not have any significant effect on occupations upon return. Even though illegal migrants seem to have lower ranked occupations compared to non-migrants upon return, the results show that the effect is not statistically significant. Table 8 reports the results on labor supply. Likewise, the results in Table 8 show that migrants' legal status does not have any significant effect on labor supply. Indeed, we find that undocumented migrants have lower labor supply compared to non-migrants, while documented migrants seem to work more than non-migrants. However, these effects are not statistically significant.

Finally, in Table 9, we examine the effect of migrants' legal status on monthly wages upon return. We estimate equation (1b), unconditional on return migration. Our main outcome of interest is the logarithm of monthly wages upon return to Egypt. We account for the various layers of selection in columns (1) to (3), and in column (4), we report the results from our structural equation. The results in Table 9 confirm that undocumented migrants witness a wage penalty with respect to both documented migrants and non-migrants. In terms of monthly wages, we find that undocumented migrants witness a wages penalty of $28 \%$ compared to non-migrants, while documented migrants witness a wage premium of $29 \%$ relative to non-migrants. In terms of monthly wages, the estimated penalty for undocumented migrants is larger in magnitude compared to the estimates presented in Section 5.1.1 in terms of hourly wages. On the other hand, the wage premium of documented migrants remains of the same magnitude.

\subsection{Underlying mechanisms: does the legal status of migrants matter while abroad?}

The results in Section 5.1 suggest that undocumented migrants fare worse upon return to Egypt compared to documented migrants but also compared to non-migrants. While documented migrants benefit from their migration experience abroad and witness a positive wage premium compared to non-migrants, undocumented migrants witness a wage penalty associated with their experience overseas. In this section, we investigate several underlying mechanisms.

In the ELMPS, individuals are asked about the reasons for return. Interestingly, we find that the primary motives for return migration differ between return migrants who had a documented migration versus those who had an undocumented migration. For example, while the most important cause of return migration is the end of the work contract for documented migrants $(26 \%)$, the primary reason for return for undocumented migrants is poor working conditions (30\%). ${ }^{25}$ In line with Gonzales (2011),

\footnotetext{
24 Elmallakh and Wahba (2021a) compute the occupational indices following Sicherman and Galor (1990) and Carletto and Kilic (2011).

25 The second most important reason for return migration among documented migrants is poor working conditions $(22 \%)$, followed by getting married (13\%), to care for family $(10 \%)$, the war in Iraq and
} 
Table 9 Estimating the effect of migrants' legal status on monthly wages after return, unconditional on return migration

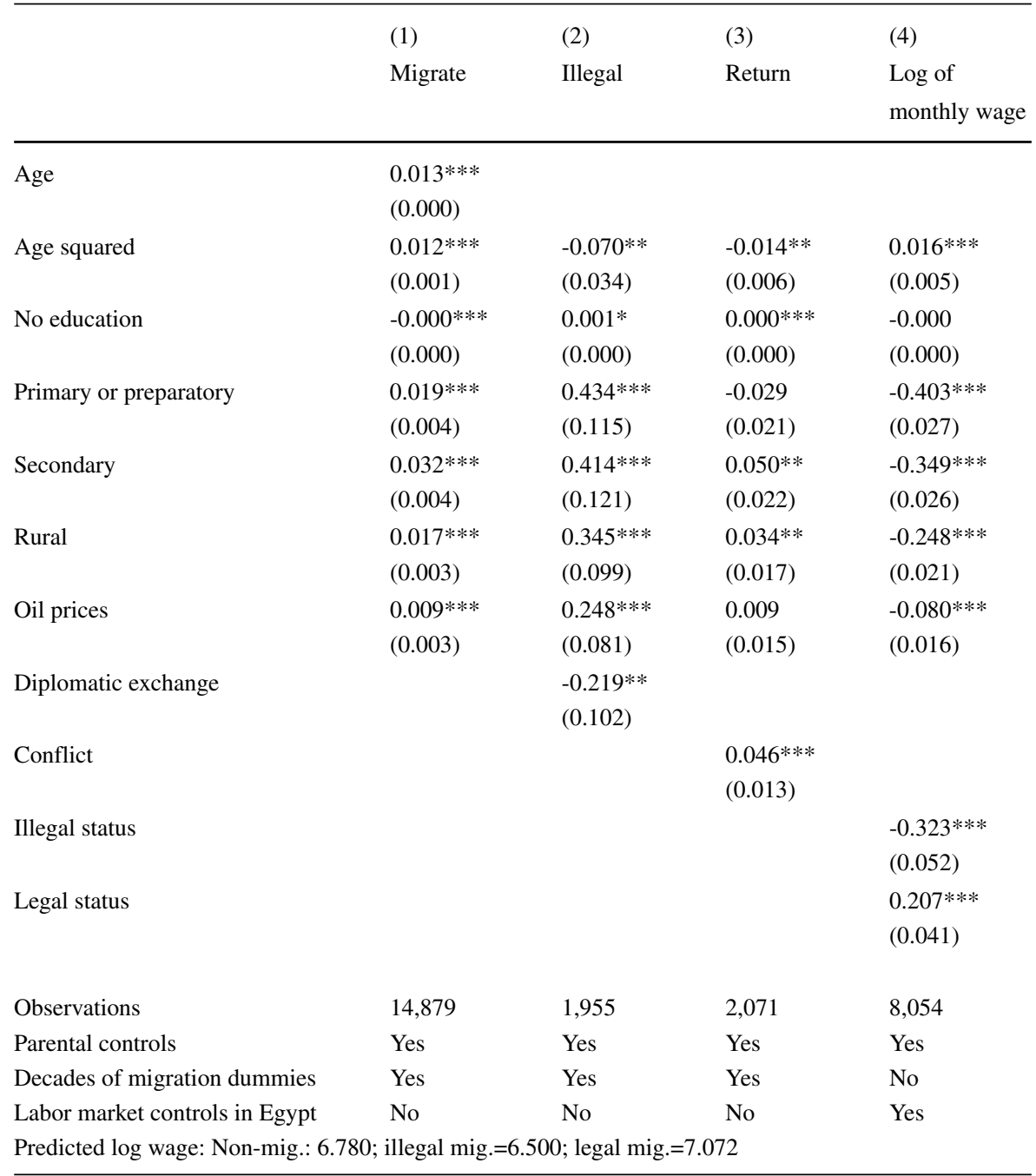

Robust standard errors in parentheses. *** $p<0.01$; ** $p<0.05 ; * p<0.1$

Equation 1 is the probability of temporary migration. Equation 2 is the probability of undocumented migration. Equation 3 is the probability of return migration. Equation 4 models the logarithm of hourly wages upon return. For identification of equation (1), we use the inflation adjusted historical oil prices (in US dollars). For identification of equation (2), we use the diplomatic exchange, which is the diplomatic representation of each country of destination of Egyptian migrants in Egypt at time of migration. It is a dummy variable equal to zero if there is no evidence of diplomatic exchange and is equal to one if there is evidence of diplomatic exchange at the level of chargé d'affaires, minister, ambassador, or other. For identification of equation (3), we use the number of active armed conflicts that is both country and year specific from the Uppsala Conflict Data Project (UCDP). Equation (4) estimates the effect of illegality on the logarithm of monthly wages, unconditional on return migration. The predicted logarithm of monthly wages for non-migrants, and migrants with legal and illegal status is reported in the last row 
Gleeson and Gonzales (2012), and Hall and Greenman (2015), this might suggest that undocumented migrants are employed in poorer jobs, which might make them less likely to benefit from their migration experience overseas compared to documented migrants. In this section, we explore the effect of migrants' illegal status on various outcomes during their migration spells abroad including: monthly wages, monthly savings, migration duration, occupations, and the probability of remitting.

In Table 10, we test for potential underlying mechanisms that could be driving our results. We rely on our benchmark CMP model to account for the triple selection into emigration, legal status, and into return. We report the results on the various selection equations in columns (1) to (3), while columns (4a) to (4e) report the results from our structural equation on various outcomes pertaining to the migration experience overseas. We estimate equation (1a), conditional on return migration. Therefore, the sample used in the estimation of our structural equations includes only return migrants (both documented and undocumented). We estimate separate models for each of the outcomes presented in columns (4a) to (4e), where we account, in each, for the various layers of selection. The first three columns: the probability of emigration, the probability of illegality, and the probability of return migration are therefore the same across models.

In line with the descriptive statistics presented in Table 13 in the Appendix, the results in Table 10 suggest that the illegal status of migrants negatively affects their monthly wages and savings, while abroad. Accounting for the triple selection into migration, illegality, and return, the results in Table 10 suggest that illegal migrants overseas earn half the wage of documented migrants. Likewise, we find that the undocumented migration status is associated with significantly lower monthly savings overseas. We also find that illegality reduces migration duration, by approximately 2 years. As we show at the bottom of Table 10, the predicted migration duration for undocumented migrants is 3 years, while the predicted duration for documented migrants is approximately 5 years.

In column (4d), we report the results on occupational ranking overseas. Our results show that migrants' illegal status is associated with a significant decline in occupational ranking. This suggests that undocumented migrants hold lower ranked occupations, while overseas, compared to documented migrants. In terms of occupational ranking, undocumented migrants seem to be employed in occupations that are on average 1 point lower, on the occupational ladder, compared to documented migrants. Finally, in column (4e), we further examine the impact of illegality on the probability of sending remittances. Controlling for wages overseas and based on the predicted probabilities of remitting in the last row of Table 10, the results show that illegality leads to a $46 \%$ reduction in the probability of sending remittances.

Overall, these results suggest that the underlying mechanism for the wage penalty experienced by undocumented migrants is driven by bad overseas jobs, i.e., human

Kuwait (7\%), and sudden termination by employer (7\%). Apart from the poor working conditions which constitute the most important reason for return migration for undocumented migrants, $17 \%$ of the latter group reported returning to get married, $15 \%$ returned due to the war in Iraq or Kuwait, $12 \%$ to care for family, $7 \%$ returned due to their work contract ending, and $4 \%$ returned due to sudden termination by the employer. 


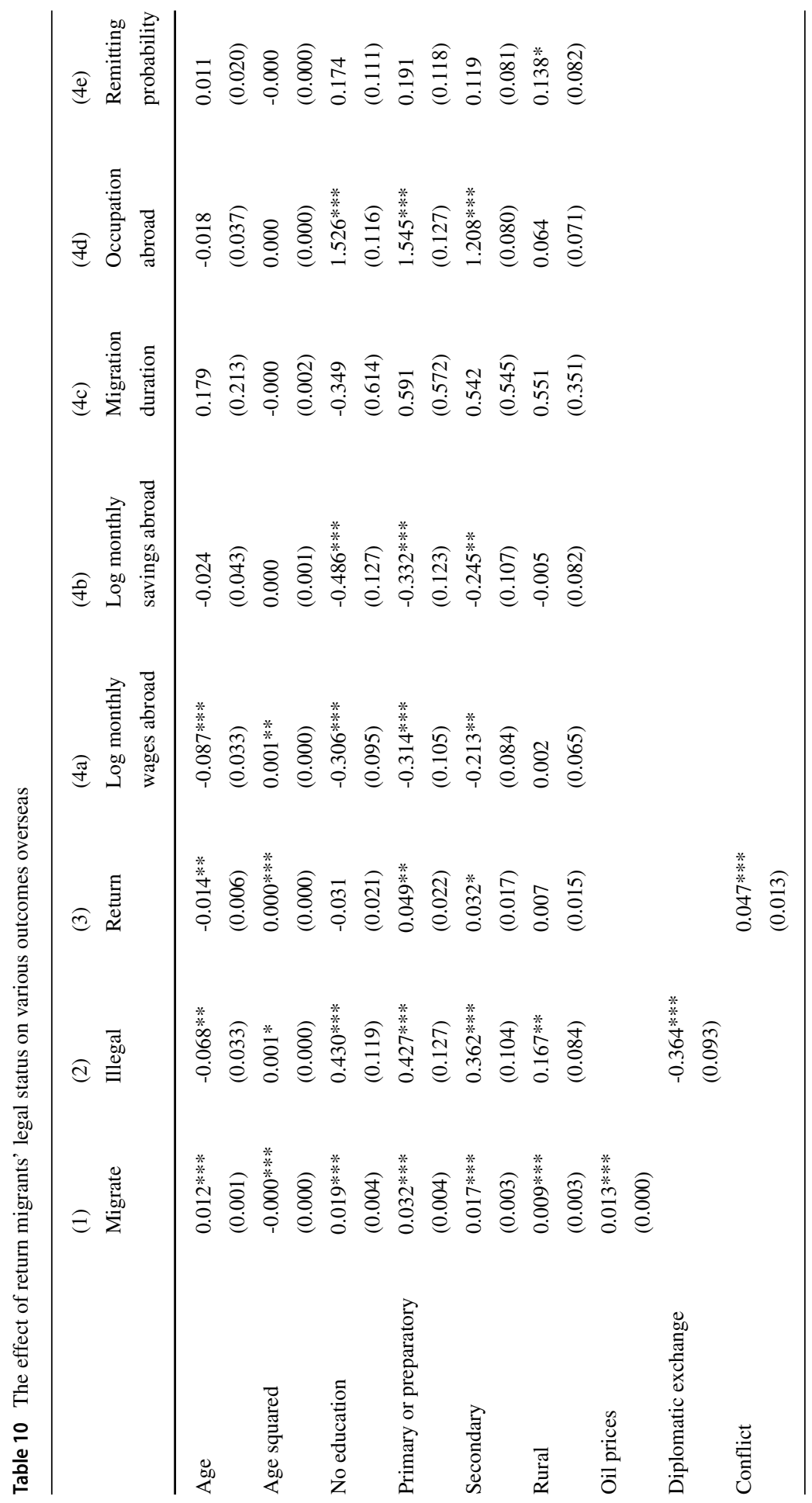




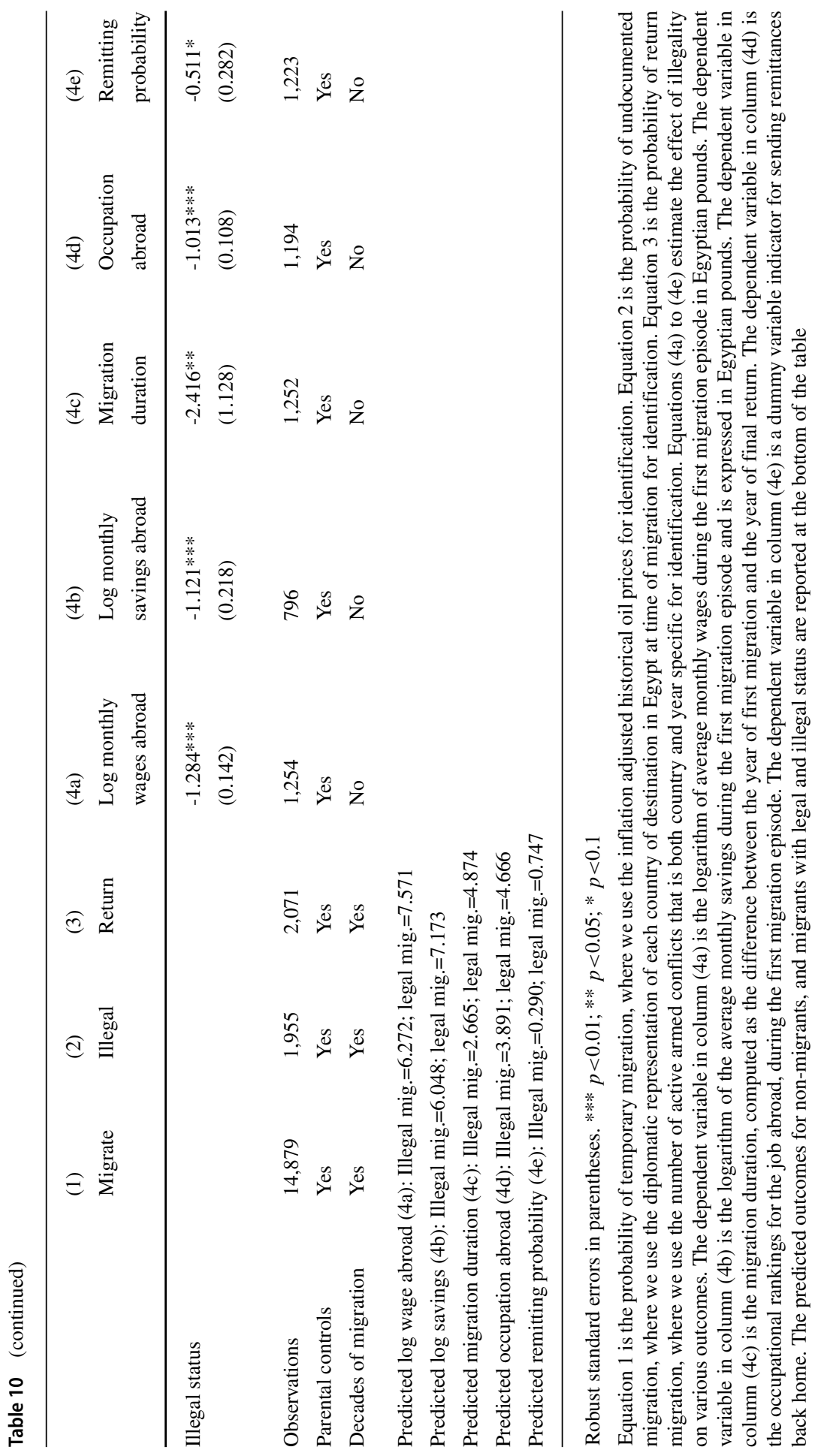


capital waste story. Indeed, we find that undocumented migrants primarily return to Egypt due to poor working conditions in the destination. We further showed in this section that migrants' illegal status is associated with lower ranked occupations overseas. These lower ranked jobs are also associated with lower earnings, lower savings, and lower incidence to send remittances. While documented migrants enhance their human capital overseas, which leads to remuneration gains upon return, our findings suggest that the migration experience of an undocumented migrant depletes their human capital, leading to wage losses upon return.

\subsection{Discussion on other selection issues}

Our benchmark results deal with three layers of selection, namely, the selection into emigration, the selection into the legal status, and the selection into return migration. Nonetheless, other selectivity or endogeneity issues might still be a source of concern. For instance, it seems reasonable to expect that (observable and unobservable) individual characteristics affect the choice of destination, or that emigrants choose between different destination countries, taking into account changes in the relative payoffs from moving to one country versus another. This might be problematic if the differential returns that we estimate are due to the different groups of countries that documented and undocumented migrants decide to choose as their destinations.

While our model does not explicitly deal with multiple destination choices, we address this concern by comparing Egyptian workers who migrated to the same country of destination, as either documented or undocumented migrants, to identify the causal impact of legal status on wages back home. In Table 11, we restrict our analysis to returnees from Iraq, the most important country of return migration when estimating equation (1b). In this equation, our analysis is restricted to returnees from Iraq, while returnees from all other countries are excluded from the sample. Comparing documented and undocumented Egyptian migrants who went to the same country of destination, Iraq, the results in Table 11 consistently point out to a wage penalty associated with undocumented migration, and to a wage premium witnessed by documented migrants.

Furthermore, the data shows that both documented and undocumented migrants choose the same pool of destination countries, at the exception of western countries where we only observe documented migrants. To make sure that our results are therefore not driven by these differential destination choices, in Table 15 in the Appendix, we also exclude return migrants from all Western countries. ${ }^{26}$ Our results also hold after excluding this subset of destination countries. These two tests therefore confirm that our findings are not driven by differential destination choices made by documented and undocumented migrants.

Another potential concern is the endogeneity of the migration duration. This would be problematic if the wage penalty of undocumented return migrants is due to their shorter migration duration compared to documented migrants. While we cannot

\footnotetext{
26 Western countries include the USA, the UK, the Netherlands, France, Austria, Czech Republic, Italy, Greece, Cyprus, Bulgaria, Romania, Iceland, and Japan.
} 
Table 11 Robustness checks, restricting the analysis to Iraq. Estimating the effect of migrants' legal status on hourly wages after return, unconditional on return migration

\begin{tabular}{|c|c|c|c|c|}
\hline & $\begin{array}{l}\text { (1) } \\
\text { Migrate }\end{array}$ & $\begin{array}{l}(2) \\
\text { Illegal }\end{array}$ & $\begin{array}{l}\text { (3) } \\
\text { Return }\end{array}$ & $\begin{array}{l}(4) \\
\text { Log of } \\
\text { hourly wage }\end{array}$ \\
\hline Age & $\begin{array}{l}0.012 * * * \\
(0.001)\end{array}$ & $\begin{array}{l}-0.077 * * \\
(0.034)\end{array}$ & $\begin{array}{l}-0.014 * * \\
(0.006)\end{array}$ & $\begin{array}{l}-0.000 \\
(0.005)\end{array}$ \\
\hline Age squared & $\begin{array}{l}-0.000 * * * \\
(0.000)\end{array}$ & $\begin{array}{l}0.001 * * \\
(0.000)\end{array}$ & $\begin{array}{l}0.000 * * * \\
(0.000)\end{array}$ & $\begin{array}{l}0.000^{* *} \\
(0.000)\end{array}$ \\
\hline No education & $\begin{array}{l}0.019 * * * \\
(0.004)\end{array}$ & $\begin{array}{l}0.519 * * * \\
(0.119)\end{array}$ & $\begin{array}{l}-0.030 \\
(0.021)\end{array}$ & $\begin{array}{l}-0.450 * * * \\
(0.026)\end{array}$ \\
\hline Primary or preparatory & $\begin{array}{l}0.032 * * * \\
(0.004)\end{array}$ & $\begin{array}{l}0.491 * * * \\
(0.128)\end{array}$ & $\begin{array}{l}0.049^{* *} \\
(0.022)\end{array}$ & $\begin{array}{l}-0.420 * * * \\
(0.025)\end{array}$ \\
\hline Secondary & $\begin{array}{l}0.017 * * * \\
(0.003)\end{array}$ & $\begin{array}{l}0.373 * * * \\
(0.104)\end{array}$ & $\begin{array}{l}0.033^{*} \\
(0.017)\end{array}$ & $\begin{array}{l}-0.284 * * * \\
(0.020)\end{array}$ \\
\hline Rural & $\begin{array}{l}0.009 * * * \\
(0.003)\end{array}$ & $\begin{array}{l}0.257 \text { *** } \\
(0.084)\end{array}$ & $\begin{array}{l}0.009 \\
(0.015)\end{array}$ & $\begin{array}{l}-0.027^{*} \\
(0.016)\end{array}$ \\
\hline Oil prices & $\begin{array}{l}0.013 * * * \\
(0.000)\end{array}$ & & & \\
\hline Diplomatic exchange & & $\begin{array}{l}-0.246^{* *} \\
(0.104)\end{array}$ & & \\
\hline Conflict & & & $\begin{array}{l}0.047 * * * \\
(0.013)\end{array}$ & \\
\hline Illegal status & & & & $\begin{array}{l}-0.255^{* * *} \\
(0.070)\end{array}$ \\
\hline Legal status & & & & $\begin{array}{l}0.177 * * * \\
(0.048)\end{array}$ \\
\hline Observations & 14,879 & 1,955 & 2,071 & 7,897 \\
\hline Parental controls & Yes & Yes & Yes & Yes \\
\hline Decades of migration dummies & Yes & Yes & Yes & No \\
\hline Labor market controls in Egypt & No & No & No & Yes \\
\hline
\end{tabular}

Robust standard errors in parentheses. *** $p<0.01 ; * * p<0.05 ; * p<0.1$

Equation 1 is the probability of temporary migration. Equation 2 is the probability of undocumented migration. Equation 3 is the probability of return migration. Equation 4 models the logarithm of hourly wages upon return, and is restricted to returnees from Iraq (the country with the highest share of return migration). For identification of equation (1), we use the inflation adjusted historical oil prices (in US dollars). For identification of equation (2), we use the diplomatic exchange, which is the diplomatic representation of each country of destination of Egyptian migrants in Egypt at time of migration. It is a dummy variable equal to zero if there is no evidence of diplomatic exchange and is equal to one if there is evidence of diplomatic exchange at the level of chargé d'affaires, minister, ambassador, or other. For identification of equation (3), we use the number of active armed conflicts that is both country and year specific from the Uppsala Conflict Data Project (UCDP). Equation (4) estimates the effect of illegality on the logarithm of hourly wages, unconditional on return migration. The predicted logarithm of hourly wages for non-migrants, and migrants with legal and illegal status is reported in the last row 
control for migration duration in our model since it is an endogenous variable and would be considered as a bad control, we address this challenge empirically by focusing on documented and undocumented migrants with similar migration duration. We estimate the impact of illegal status on migrants' wages upon return relying on three separate models in Table 12. First, we estimate the model by focusing on migrants who belong to the lowest 33rd percentile of the distribution of migration duration (those who have 2 years of migration or less) and we report the corresponding results in column (4a). Second, we estimate the model by considering returnees who belong to the middle 33rd percentile of the distribution with 3 to 5 years of migration and we report results in column (4b). Finally, we focus on returnees who belong to the highest 33rd percentile of migration duration with 6 years of migration or more in column (4c). The first three estimated equations: the probability of emigration, the

Table 12 Heterogeneous effects by migration duration. Estimating the effect of migrants' legal status on hourly wages after return, conditional on return migration

\begin{tabular}{|c|c|c|c|c|c|c|}
\hline & $\begin{array}{l}\text { (1) } \\
\text { Migrate }\end{array}$ & $\begin{array}{l}\text { (2) } \\
\text { Illegal }\end{array}$ & $\begin{array}{l}\text { (3) } \\
\text { Return }\end{array}$ & $\begin{array}{l}\text { (4a) } \\
\text { Log of } \\
\text { hourly } \\
\text { wage }\end{array}$ & $\begin{array}{l}(4 b) \\
\text { Log of } \\
\text { hourly } \\
\text { wage }\end{array}$ & $\begin{array}{l}(4 c) \\
\text { Log of } \\
\text { hourly } \\
\text { wage }\end{array}$ \\
\hline Age & $\begin{array}{l}0.012 * * * \\
(0.001)\end{array}$ & $\begin{array}{l}-0.074 * * \\
(0.035)\end{array}$ & $\begin{array}{l}-0.015^{* *} \\
(0.006)\end{array}$ & $\begin{array}{l}-0.046 \\
(0.050)\end{array}$ & $\begin{array}{l}0.055 \\
(0.085)\end{array}$ & $\begin{array}{l}-0.174 * \\
(0.102)\end{array}$ \\
\hline Age squared & $\begin{array}{l}-0.000^{* * *} \\
(0.000)\end{array}$ & $\begin{array}{l}0.001 * \\
(0.000)\end{array}$ & $\begin{array}{l}0.000^{* * * *} \\
(0.000)\end{array}$ & $\begin{array}{l}0.001 \\
(0.001)\end{array}$ & $\begin{array}{l}-0.001 \\
(0.001)\end{array}$ & $\begin{array}{l}0.002 * \\
(0.001)\end{array}$ \\
\hline No education & $\begin{array}{l}0.019 * * * \\
(0.004)\end{array}$ & $\begin{array}{l}0.523 * * * \\
(0.121)\end{array}$ & $\begin{array}{l}-0.032 \\
(0.021)\end{array}$ & $\begin{array}{l}-0.567 * * * \\
(0.154)\end{array}$ & $\begin{array}{l}-0.186 \\
(0.189)\end{array}$ & $\begin{array}{l}-0.503^{*} \\
(0.277)\end{array}$ \\
\hline Primary or preparatory & $\begin{array}{l}0.032 * * * \\
(0.004)\end{array}$ & $\begin{array}{l}0.482 * * * \\
(0.130)\end{array}$ & $\begin{array}{l}0.048^{* *} \\
(0.022)\end{array}$ & $\begin{array}{l}-0.383^{* * *} \\
(0.138)\end{array}$ & $\begin{array}{l}-0.456 * * \\
(0.179)\end{array}$ & $\begin{array}{l}-0.684 * * \\
(0.303)\end{array}$ \\
\hline Secondary & $\begin{array}{l}0.017 * * * \\
(0.003)\end{array}$ & $\begin{array}{l}0.418^{* * *} \\
(0.107)\end{array}$ & $\begin{array}{l}0.032 * \\
(0.017)\end{array}$ & $\begin{array}{l}-0.258^{* *} \\
(0.119)\end{array}$ & $\begin{array}{l}0.013 \\
(0.136)\end{array}$ & $\begin{array}{l}-0.200 \\
(0.179)\end{array}$ \\
\hline Rural & $\begin{array}{l}0.009 * * * \\
(0.003)\end{array}$ & $\begin{array}{l}0.255^{* * *} \\
(0.086)\end{array}$ & $\begin{array}{l}0.008 \\
(0.015)\end{array}$ & $\begin{array}{l}-0.088 \\
(0.085)\end{array}$ & $\begin{array}{l}0.026 \\
(0.117)\end{array}$ & $\begin{array}{l}-0.013 \\
(0.163)\end{array}$ \\
\hline Oil prices & $\begin{array}{l}0.013 * * * \\
(0.000)\end{array}$ & & & & & \\
\hline Diplomatic exchange & & $\begin{array}{l}-0.273^{* * *} \\
(0.104)\end{array}$ & & & & \\
\hline Conflict & & & $\begin{array}{l}0.044 * * * \\
(0.013)\end{array}$ & & & \\
\hline Illegal status & & & & $\begin{array}{l}0.079 \\
(0.311)\end{array}$ & $\begin{array}{l}-0.574 * \\
(0.296)\end{array}$ & $\begin{array}{l}-0.671^{*} \\
(0.401)\end{array}$ \\
\hline
\end{tabular}


Table 12 (continued)

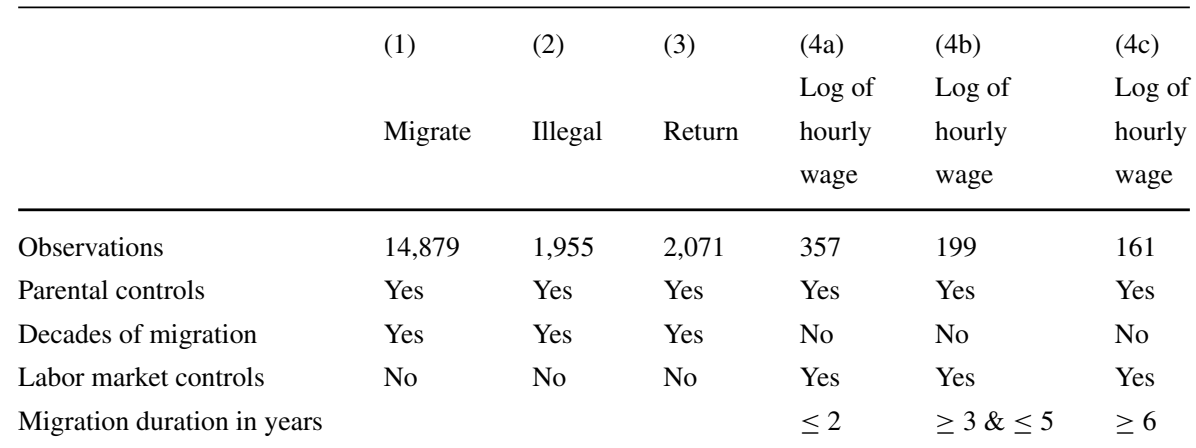

Predicted log of hourly wage (4a): Illegal mig. $=1.613$; legal mig. $=1.523$

Predicted log of hourly wage (4b): Illegal mig.=1.306; legal mig. $=1.902$

Predicted $\log$ of hourly wage (4c): Illegal mig. $=1.183$; legal mig. $=1.926$

Robust standard errors in parentheses. $* * * p<0.01$; ** $p<0.05 ; * p<0.1$

Equation 1 is the probability of temporary migration. Equation 2 is the probability of undocumented migration. Equation 3 is the probability of return migration. Equation 4 models the logarithm of hourly wages upon return. For identification of equation (1), we use the inflation adjusted historical oil prices (in US dollars). For identification of equation (2), we use the diplomatic exchange, which is the diplomatic representation of each country of destination of Egyptian migrants in Egypt at time of migration. It is a dummy variable equal to zero if there is no evidence of diplomatic exchange and is equal to one if there is evidence of diplomatic exchange at the level of chargé d'affaires, minister, ambassador, or other. For identification of equation (3), we use the number of active armed conflicts that is both country and year specific from the Uppsala Conflict Data Project (UCDP). Equations (4a), (4b), and (4c) estimate the effect of illegality on the logarithm of hourly wages, conditional on return migration. Three models are separately estimated, relying on the percentile distribution of migration duration. In equation (4a), we consider individuals who belong to the lowest 33rd percentile of the distribution (with 2 years of migration duration or less). In equation (4b), we consider individuals who belong to the middle 33rd percentile of the distribution (with 3 to 5 years of migration). In equation (4c), we consider individuals who belong to the highest 33rd percentile of the distribution (with 6 years of migration or more). The predicted logarithm of hourly wages for and migrants with legal and illegal status in equations (4a) to (4c) is reported in the bottom of the table

probability of illegality, and the probability of return migration are the same across the three models. Interestingly, we find that the results are mostly driven by returnees who belong to the upper end of the migration duration distribution-those with 3 years of migration duration or more. Moreover, it is interesting to note that the wage gap between documented and undocumented return migrants grows bigger the longer the migrants stay abroad. Indeed, the predicted probabilities reported at the bottom of Table 12 show that documented migrants' predicted hourly wage upon return appreciates with the length of stay abroad, while undocumented migrants' predicted hourly wage depreciates the longer the migrant's migration spell. These dynamics address the concern that undocumented migrants are faring worse due to the shorter migration spells as these results, in fact, show the opposite dynamic; the longer undocumented migrants stay abroad, the more their human capital is depleted. These dynamics are 
also fully consistent with the theoretical argument of human capital waste for undocumented migrants and on the other hand, with greater human capital accumulation for documented migrants.

\section{Robustness checks}

\subsection{Alternative definitions}

Throughout the paper, we define undocumented migrants as those who (1) did not have a visa or official document to enter the destination country if the country required an entry visa, (2) were working without a work contract for countries that had a visa waiver for Egyptians, or (3) had a work permit, a tourist visa, a visit visa, or a temporary residence permit but were working in the destination without any work contract to capture over-stayers. In this section, we rely on an alternative definition of undocumented migration. We simply define undocumented migrants as those who either entered the destination country without a visa or an official document for countries that required an entry visa or those who did not have a work contract for their employment abroad in countries that did not require an entry visa for Egyptians. Elmallakh and Wahba (2021a) show that the results are consistently robust to using this alternative definition of undocumented migration.

We also checked the robustness of our results with respect to the definition of diplomatic representation for the identification of the illegality equation. In our benchmark model, we use the diplomatic representation of each country of destination of the migrants in Egypt. To check the robustness of our results, we also use two alternative definitions. The first one captures instead the diplomatic representation of Egypt in each country of destination of migrants at the time of migration. It is a dummy variable equal to one if Egypt is diplomatically represented in the country of destination at the time of migration and zero, otherwise. The second definition captures the diplomatic representation in both Egypt and the country of destination of the migrants at the time of migration. In this case, the dummy variable takes the value one if there is diplomatic representation in both Egypt and the country of destination of the migrant at the time of migration and zero, otherwise. Elmallakh and Wahba (2021a) show that the results are also robust to these additional checks and remain stable in magnitude.

\subsection{Alternative specifications}

In this section, we check the robustness of our results to alternative specifications of our benchmark model. In the model we present in Section 4.1, there are three selection processes, namely migration, legal status of migrants, and return migration. Our benchmark model implicitly assumes that the legal status of migrants does not have an impact on return migration. However, it might be possible that the return migration decision and migrants' legal status are closely linked.

Elmallakh and Wahba (2021a) also check the robustness of the results to incorporating the legal status into the return migration equation (4) — which models the return 
migration decision - therefore includes a dummy variable for illegal migration. We find a negative coefficient of illegality in the return migration equation, although it is not statistically significant. This suggests that there is no significant association between illegality and return decisions. As for the results from our structural equation, we consistently show that undocumented migration is associated with a wage penalty, while documented migrants witness a significant wage premium upon return. The magnitude of the estimated wage penalty and premium are $17 \%$ and $27 \%$, respectively. Our benchmark results reported in Table 6 were associated with an estimated wage penalty of $19 \%$ and a wage premium of $28 \%$. These effects are therefore very comparable in terms of magnitude.

As presented in Section 4.2, we also check the validity of the exclusion restriction of conflict occurrence. Since our instrument could only be predicting forced return migration due to armed conflicts and not planned return migration, we also control for unemployment rate in the destination country in the return migration equation. The unemployment rate is both country and year specific. For return migrants, the unemployment rate is matched with the year of return migration, while we matched the unemployment rate at the time of the survey in 2012 for current migrants.

We report our results in Table 16 in the Appendix. We deal with the selection into emigration, legal status, and into return in columns (1) to (3). For the identification of the return migration equation, column (3) includes both the number of active armed conflicts and the unemployment rate in the destination. We find that both variables are positively associated with return migration. While an additional armed conflict in the destination country increases the probability of return migration by 2.8 percentage points, we find that a $1 \%$ increase in unemployment rate at destination is associated with $0.7 \%$ increase in the return probability. The results from our structural equation are reported in column (4) and are consistently robust to controlling for unemployment rates at destination in the return migration equation.

A related issue is that conflicts might have consequences on the Egyptian economy through, for instance, changes in trade flows, foreign direct investments, or remittances. In Table 17 in the Appendix, we check the robustness of our results to controlling for the following variables in Egypt in the return migration equation: FDI (\% of GDP), remittances (\% of GDP), and the exports and imports of goods and services (\% of GDP) ${ }^{27}$ Our results from the structural equation in column (4) are also consistently robust to controlling for these variables.

\subsection{Using 2018 data}

In this paper, we rely on data from the ELMPS 2012. Indeed, the 2012 survey is advantageous as it oversampled areas with high migration rates. As we discussed in Section 3.1, the most recent ELMPS data was conducted in 2018 and instead oversampled rural communities in Egypt. Nonetheless, in this section, we replicate our analysis using the most recent publicly available survey as a robustness check.

\footnotetext{
27 Data comes from the World Bank Development Indicators. These variables are matched with the year of migration for return migrants and at the time of the survey in 2012 for current migrants. The results were also robust to controlling for these variables in the structural equation in column (4).
} 
We examine the effect of migrants' legal status on hourly wages in 2018, unconditional on return migration, by estimating equation (1b). In Table 18 in the Appendix, we report our results unconditional on return migration. We account for the various selection processes in columns (1) to (3) following the same identification strategy presented in Section 4.1. In line with our benchmark results presented in Section 5.1.1, we find that only documented migrants witness a wage premium relative to non-migrants, while undocumented migrants witness a wage penalty.

Elmallakh and Wahba (2021a) also check the robustness of the results to using pooled cross-sectional data from the 2012 and 2018 ELMPS. The model additionally includes a year fixed effect for the 2018 survey. Our results consistently show that undocumented migration is associated with a wage penalty, while migrants' legal status leads to a positive wage premium upon return.

Relying on the 2018 data, we also analyze the dynamics of the effects. We ask whether the effect of legal status remains constant over time after return or varies. Accounting for the triple selection in columns (1) to (3), column (4) reports the results from the structural equation. To capture the dynamics of the effects, instead of focusing on the full 2018 sample as in Table 18, we restrict our analysis, in Table 19, to individuals who were interviewed in both ELMPS 2012 and 2018. We therefore track the same individuals included in our benchmark analysis in the 2018 survey. Our results consistently point to a wage penalty for undocumented migrants of $54 \%$ and to a wage premium for documented migrants of $16 \%$. Comparing the magnitude of these effects with those from our benchmark model in Section 5.1.1, we find that undocumented migrants' wage penalty grew larger over time. Moreover, while documented migrants still witness a significant wage premium upon return, our results show that legal migrants' wage premium was actually larger in 2012 (28\%). The evidence therefore suggests that the wage gap between non-migrants and undocumented migrants grew larger over time, while the wage gap between documented migrants and non-migrants narrowed down.

\subsection{Other robustness checks}

As we discussed earlier in the paper, the incidence of multiple migration episodes is very low in Egypt. In our dataset, approximately $95 \%$ of return migrants had one or two migration episodes and less than $5 \%$ had more than two migration episodes. Elmallakh and Wahba (2021a) also exclude individuals who had more than two migration episodes and show that the results are also robust to this check.

Finally, we check whether the differential results that we observed are due to differences in the reasons of return between documented and undocumented migrants. In Table 20 in the Appendix, we estimate two distinct models. Columns (1), (2), and (3) are the same across the two models, while in the first model, we focus on voluntary return migration (column 4a), and in the second model, we focus on involuntary return migration (column 4b). Voluntary reasons are the following: individuals return to get married, to set up business at home country, to take over family business or farm, due to poor working conditions, to care for family, to study, or due to an appointment. On the other hand, involuntary reasons 
include contract ended, sudden termination by employer, retirement, health problems, the war in Iraq or Kuwait, accident or illness, death, or compulsory military service. The estimates in columns (4a) and (4b) allow us to compare documented and undocumented migrants who returned due to voluntary or involuntary reasons, respectively.

Interestingly, we find that voluntary returns are associated with a wage penalty for undocumented migrants and a wage premium for documented migrants. On the other hand, we find that undocumented migrants who returned involuntary do not witness a wage penalty, while documented migrants still witness a wage premium. Indeed, we find that undocumented migrants who returned involuntary have lower migration duration (average migration duration is 3.6 years with a standard deviation of 3.7), while undocumented migrants who returned voluntary have on average 5.8 years of migration duration with a standard deviation of 6.6. In line with our results in Table 12, these differential effects might be associated with the length of the migration spell abroad. These results confirm once again that the longer undocumented migrants stay abroad, the more their human capital is depleted.

\section{Concluding remarks}

This paper examines the impact of the legal status of temporary overseas migration on migrants' wages upon return to the home country. Using unique data from Egypt, we distinguish between return migrants according to their type of international migration-documented versus undocumented-and examine the impact of temporary migration on wages upon return. Relying on a conditional mixed process model, which takes into account the triple selection into emigration, illegality, and return migration, we examine the effect of illegality on wages upon return.

Our findings show that controlling for the various layers of selection, return migrants who had an illegal status while abroad have significantly lower earnings upon return compared to both documented return migrants and non-migrants. This suggests that undocumented migrants do not gain from their overseas migration experience in terms of skill acquisition the way documented migrants do. Our results show that the longer undocumented migrants stay abroad, the more their human capital is depleted, while the opposite is true for documented migrants. Indeed, we find evidence that undocumented migrants experience a waste of human capital overseas, as they have lower earnings and end up in lower ranked occupations while abroad, which might explain their lower earnings upon return.

Our results are the first to show the negative impact associated with illegality on the migrants, even after they return to their country of origin. These findings have important policy implications, as they suggest that there is a need to raise awareness among potential migrants about the negative consequences of illegal migration experiences. Furthermore, countries of origin should maximize the benefits of migration by supporting legal migration and curbing illegal migration. 


\section{Appendix 1}

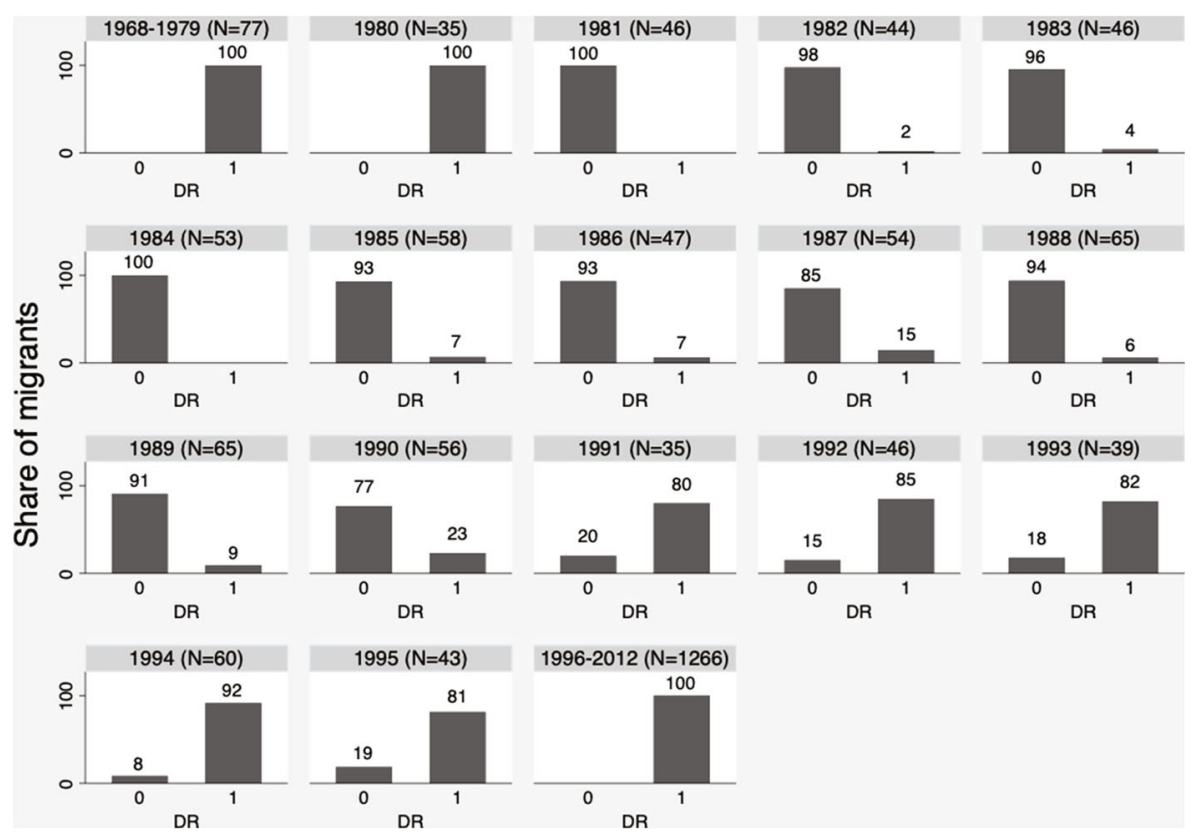

Fig. 4 Diplomatic representation and migration flows. This graph presents the share of migrants on the Y-axis and the diplomatic representation dummy on the X-axis, by year of migration. In a particular year, we calculate the share of total migrants (return and current migrants) that went to countries with zero diplomatic representation in Egypt and the share of total migrants (return and current migrants) that went to countries with diplomatic representation in Egypt. Diplomatic representation is derived from the Correlates of War Diplomatic exchange dataset 
Table 13 Descriptive statistics: the migration experience of documented undocumented return migrants

\begin{tabular}{|c|c|c|c|c|c|}
\hline & \multicolumn{2}{|c|}{$\begin{array}{l}\text { Documented } \\
\text { migrants }\end{array}$} & \multicolumn{2}{|c|}{$\begin{array}{l}\text { Undocumented } \\
\text { migrants }\end{array}$} & \multirow[b]{2}{*}{ (5) } \\
\hline & (1) & (2) & (3) & (4) & \\
\hline & Mean & St. Dev. & Mean & St. Dev. & Difference \\
\hline Monthly income abroad in EGP & 2,112 & 2,195 & 1,278 & 1,294 & $834.335^{* * *}$ \\
\hline Monthly savings abroad in EGP & 1,606 & 2,121 & 1,167 & 1,639 & $439.384 * *$ \\
\hline Incidence of remittances & 0.604 & 0.490 & 0.521 & 0.500 & $0.083^{* *}$ \\
\hline Monthly remittances in EGP & 2,002 & 3,247 & 1,090 & 1,932 & $911.367 * *$ \\
\hline Migration duration & 4.344 & 4.251 & 3.468 & 3.561 & $0.876^{* * *}$ \\
\hline Number of migration episodes & 1.220 & 0.817 & 1.174 & 0.448 & 0.046 \\
\hline \multicolumn{6}{|l|}{ Year of migration } \\
\hline 1970-1979 & 0.032 & 0.176 & 0.050 & 0.218 & -0.018 \\
\hline 1980-1989 & 0.309 & 0.463 & 0.475 & 0.500 & $-0.166 * * *$ \\
\hline 1990-1999 & 0.243 & 0.429 & 0.170 & 0.376 & $0.072 * *$ \\
\hline 2000-2009 & 0.389 & 0.488 & 0.284 & 0.452 & $0.105 * * *$ \\
\hline 2010-2012 & 0.023 & 0.150 & 0.018 & 0.132 & 0.005 \\
\hline \multicolumn{6}{|l|}{ Year of return } \\
\hline 1970-1979 & 0.007 & 0.083 & 0.011 & 0.103 & -0.004 \\
\hline 1980-1989 & 0.166 & 0.372 & 0.306 & 0.462 & $-0.140 * * *$ \\
\hline 1990-1999 & 0.295 & 0.457 & 0.302 & 0.460 & -0.008 \\
\hline 2000-2009 & 0.380 & 0.486 & 0.263 & 0.441 & $0.117 * * *$ \\
\hline 2010-2012 & 0.138 & 0.346 & 0.117 & 0.323 & 0.021 \\
\hline \multicolumn{6}{|l|}{ Countries of destination } \\
\hline Libya & 0.131 & 0.337 & 0.292 & 0.455 & $-0.161 * * *$ \\
\hline Jordan & 0.128 & 0.335 & 0.149 & 0.357 & -0.020 \\
\hline Saudi Arabia & 0.359 & 0.480 & 0.039 & 0.194 & $0.320 * * *$ \\
\hline Iraq & 0.181 & 0.386 & 0.445 & 0.498 & $-0.264 * * *$ \\
\hline United Arab Emirates & 0.064 & 0.245 & 0.028 & 0.167 & $0.036^{* *}$ \\
\hline Kuwait & 0.067 & 0.249 & 0.011 & 0.103 & $0.056^{* * *}$ \\
\hline Other countries & 0.071 & 0.257 & 0.039 & 0.194 & $0.032 *$ \\
\hline Observations & 437 & & 282 & & \\
\hline
\end{tabular}

*** $p<0.01 ; * * p<0.05$; * $p<0.1$

Column 5 is $t$-test for whether the difference in means between the two groups is statistically significant 
Table 14 Time variation in diplomatic representation

\begin{tabular}{ll}
\hline & $\begin{array}{l}\text { Percent of destination countries } \\
\text { with diplomatic representation in Egypt }\end{array}$ \\
\hline 1955 & 0.870 \\
1960 & 0.760 \\
1965 & 0.759 \\
1970 & 0.862 \\
1975 & 0.857 \\
1980 & 0.457 \\
1985 & 0.543 \\
1990 & 0.865 \\
1995 & 0.944 \\
2000 & 0.944 \\
2005 & 0.972 \\
\hline
\end{tabular}

This table presents the share of countries with diplomatic representation in Egypt by year. Information on diplomatic representation from the Correlates of War Diplomatic exchange dataset is available every five years between 1950 and 2005. We restrict the analysis to the full sample of all destination countries 
Table 15 Robustness checks, excluding all western countries. Estimating the effect of migrants' legal status on hourly wages after return, unconditional on return migration

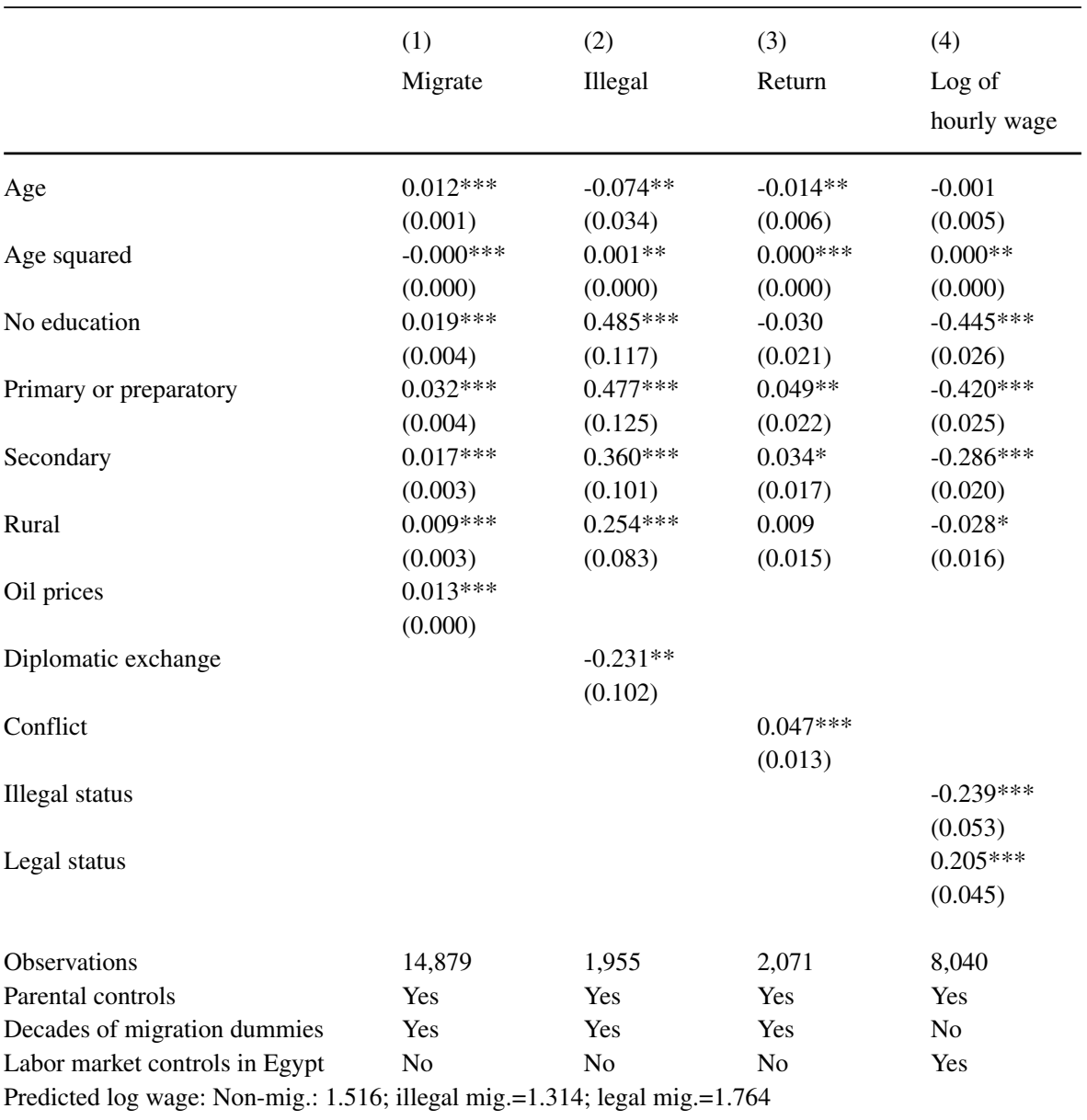

Robust standard errors in parentheses. $* * * p<0.01$; ** $p<0.05 ; * p<0.1$

Equation 1 is the probability of temporary migration. Equation 2 is the probability of undocumented migration. Equation 3 is the probability of return migration. Equation 4 models the logarithm of hourly wages upon return, and excludes returnees from all western countries. For identification of equation (1), we use the inflation adjusted historical oil prices (in US dollars). For identification of equation (2), we use the diplomatic exchange, which is the diplomatic representation of each country of destination of Egyptian migrants in Egypt at time of migration. It is a dummy variable equal to zero if there is no evidence of diplomatic exchange and is equal to one if there is evidence of diplomatic exchange at the level of chargé d'affaires, minister, ambassador, or other. For identification of equation (3), we use the number of active armed conflicts that is both country and year specific from the Uppsala Conflict Data Project (UCDP). Equation (4) estimates the effect of illegality on the logarithm of hourly wages, unconditional on return migration. The predicted logarithm of hourly wages for non-migrants, and migrants with legal and illegal status is reported in the last row 
Table 16 Robustness checks, controlling for unemployment rates at destination. Estimating the effect of migrants' legal status on hourly wages after return, unconditional on return

\begin{tabular}{|c|c|c|c|c|}
\hline & $\begin{array}{l}\text { (1) } \\
\text { Migrate }\end{array}$ & $\begin{array}{l}(2) \\
\text { Illegal }\end{array}$ & $\begin{array}{l}\text { (3) } \\
\text { Return }\end{array}$ & $\begin{array}{l}\text { (4) } \\
\text { Log of } \\
\text { hourly wage }\end{array}$ \\
\hline Age & $\begin{array}{l}0.012 * * * \\
(0.001)\end{array}$ & $\begin{array}{l}-0.071 * * \\
(0.034)\end{array}$ & $\begin{array}{l}-0.011 \\
(0.007)\end{array}$ & $\begin{array}{l}-0.001 \\
(0.005)\end{array}$ \\
\hline Age squared & $\begin{array}{l}-0.000 * * * \\
(0.000)\end{array}$ & $\begin{array}{l}0.001 * \\
(0.000)\end{array}$ & $\begin{array}{l}0.000 * * \\
(0.000)\end{array}$ & $\begin{array}{l}0.000 * * \\
(0.000)\end{array}$ \\
\hline No education & $\begin{array}{l}0.019 * * * \\
(0.004)\end{array}$ & $\begin{array}{l}0.483 * * * \\
(0.117)\end{array}$ & $\begin{array}{l}-0.066 * * * \\
(0.024)\end{array}$ & $\begin{array}{l}-0.445 * * * \\
(0.026)\end{array}$ \\
\hline Primary or preparatory & $\begin{array}{l}0.032 * * * \\
(0.004)\end{array}$ & $\begin{array}{l}0.478^{* * * *} \\
(0.126)\end{array}$ & $\begin{array}{l}0.022 \\
(0.024)\end{array}$ & $\begin{array}{l}-0.420 * * * \\
(0.025)\end{array}$ \\
\hline Secondary & $\begin{array}{l}0.017 * * * \\
(0.003)\end{array}$ & $\begin{array}{l}0.359 * * * \\
(0.102)\end{array}$ & $\begin{array}{l}0.013 \\
(0.019)\end{array}$ & $\begin{array}{l}-0.285^{* * *} * \\
(0.020)\end{array}$ \\
\hline Rural & $\begin{array}{l}0.009 * * * \\
(0.003)\end{array}$ & $\begin{array}{l}0.259 * * * \\
(0.082)\end{array}$ & $\begin{array}{l}0.011 \\
(0.017)\end{array}$ & $\begin{array}{l}-0.028 * \\
(0.016)\end{array}$ \\
\hline Oil prices & $\begin{array}{l}0.013 \text { *** } \\
(0.000)\end{array}$ & & & \\
\hline Diplomatic exchange & & $\begin{array}{l}-0.285^{* * * *} \\
(0.103)\end{array}$ & & \\
\hline Conflict & & & $\begin{array}{l}0.028 * \\
(0.016)\end{array}$ & \\
\hline Unemployment at destination & & & $\begin{array}{l}0.007 * * * \\
(0.001)\end{array}$ & \\
\hline Illegal status & & & & $\begin{array}{l}-0.237 * * * \\
(0.052)\end{array}$ \\
\hline Legal status & & & & $\begin{array}{l}0.207^{* * *} * \\
(0.044)\end{array}$ \\
\hline Observations & 14,879 & 1,955 & 1,690 & 8,054 \\
\hline Parental controls & Yes & Yes & Yes & Yes \\
\hline Decades of migration dummies & Yes & Yes & Yes & No \\
\hline Labor market controls in Egypt & No & No & No & Yes \\
\hline
\end{tabular}

Robust standard errors in parentheses. *** $p<0.01$; ** $p<0.05 ; * p<0.1$

Equation 1 is the probability of temporary migration. Equation 2 is the probability of undocumented migration. Equation 3 is the probability of return migration. Equation 4 models the logarithm of hourly wages upon return. Equation (3) additionally controls for the unemployment rate at destination at the time of return migration (for return migrants) and at the time of the survey in 2012 (for current migrants). For identification of equation (1), we use the inflation adjusted historical oil prices (in US dollars). For identification of equation (2), we use diplomatic exchange between Egypt and the countries of destination of Egyptian migrants at time of migration. It is a dummy variable equal to zero if there is no evidence of diplomatic exchange neither in Egypt nor in the country of destination and is equal to one if there is evidence of diplomatic exchange either in Egypt or in the country of destination at the level of chargé d'affaires, minister, ambassador, or other. For identification of equation (3), we use the number of active armed conflicts that is both country and year specific from the Uppsala Conflict Data Project (UCDP). Equation (4) estimates the effect of illegality on the logarithm of hourly wages, unconditional on return migration. The predicted logarithm of hourly wages for non-migrants, and migrants with legal and illegal status is reported in the last row 
Table 17 Robustness checks, controlling for trade, FDI and remittances. Estimating the effect of migrants' legal status on wages after return, unconditional on return

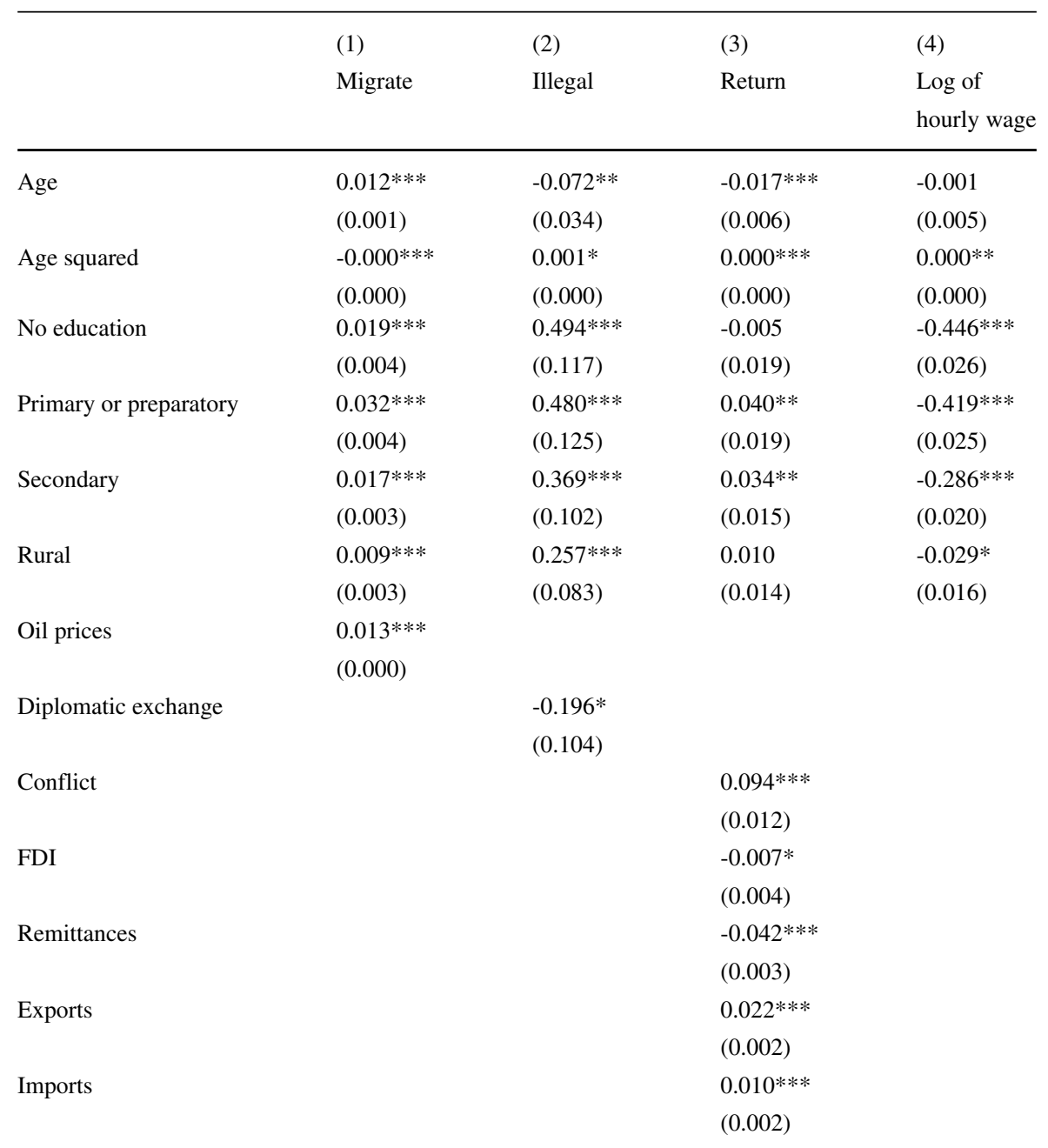


Table 17 (continued)

\begin{tabular}{|c|c|c|c|c|}
\hline & $\begin{array}{l}(1) \\
\text { Migrate }\end{array}$ & $\begin{array}{l}(2) \\
\text { Illegal }\end{array}$ & $\begin{array}{l}\text { (3) } \\
\text { Return }\end{array}$ & $\begin{array}{l}\text { (4) } \\
\text { Log of } \\
\text { hourly wage }\end{array}$ \\
\hline Illegal status & & & & $\begin{array}{l}-0.208^{* * *} \\
(0.055)\end{array}$ \\
\hline Legal status & & & & $\begin{array}{l}0.185^{* * * *} \\
(0.046)\end{array}$ \\
\hline Observations & 14,879 & 1,955 & 2,064 & 8,054 \\
\hline Parental controls & Yes & Yes & Yes & Yes \\
\hline Decades of migration dummies & Yes & Yes & Yes & No \\
\hline Labor market controls in Egypt & No & No & No & Yes \\
\hline
\end{tabular}

Robust standard errors in parentheses. *** $p<0.01$; ** $p<0.05$; * $p<0.1$

Equation 1 is the probability of temporary migration. Equation 2 is the probability of undocumented migration. Equation 3 is the probability of return migration. Equation 4 models the logarithm of hourly wages upon return. Equation (4) controls for FDI, remittances, and the exports and imports of goods and services (all as \% of GDP). For identification of equation (1), we use the inflation adjusted historical oil prices (in US dollars). For identification of equation (2), we use diplomatic exchange between Egypt and the countries of destination of Egyptian migrants at time of migration. It is a dummy variable equal to zero if there is no evidence of diplomatic exchange neither in Egypt nor in the country of destination and is equal to one if there is evidence of diplomatic exchange either in Egypt or in the country of destination at the level of chargé d'affaires, minister, ambassador, or other. For identification of equation (3), we use the number of active armed conflicts that is both country and year specific from the Uppsala Conflict Data Project (UCDP). Equation (4) estimates the effect of illegality on the logarithm of hourly wages, conditional on return migration. The predicted logarithm of hourly wages for non-migrants, and migrants with legal and illegal status is reported in the last row 
Table 18 Robustness checks, using 2018 data. Estimating the effect of migrants' legal status on wages after return, unconditional on return (continued)

\begin{tabular}{|c|c|c|c|c|}
\hline & $\begin{array}{l}\text { (1) } \\
\text { Migrate }\end{array}$ & $\begin{array}{l}(2) \\
\text { Illegal }\end{array}$ & $\begin{array}{l}(3) \\
\text { Return }\end{array}$ & $\begin{array}{l}(4) \\
\text { Log of } \\
\text { hourly wage }\end{array}$ \\
\hline Age & $\begin{array}{l}-0.001 \\
(0.001)\end{array}$ & $\begin{array}{l}-0.042 \\
(0.037)\end{array}$ & $\begin{array}{l}0.009 \\
(0.009)\end{array}$ & $\begin{array}{l}-0.002 \\
(0.005)\end{array}$ \\
\hline Age squared & $\begin{array}{l}0.000^{* *} \\
(0.000)\end{array}$ & $\begin{array}{l}0.000 \\
(0.000)\end{array}$ & $\begin{array}{l}-0.000 \\
(0.000)\end{array}$ & $\begin{array}{l}0.000 \\
(0.000)\end{array}$ \\
\hline No education & $\begin{array}{l}0.002 \\
(0.002)\end{array}$ & $\begin{array}{l}0.444 * * * \\
(0.127)\end{array}$ & $\begin{array}{l}0.155^{* * * *} \\
(0.035)\end{array}$ & $\begin{array}{l}-0.332 * * * \\
(0.026)\end{array}$ \\
\hline Primary or preparatory & $\begin{array}{l}0.001 \\
(0.003)\end{array}$ & $\begin{array}{l}0.243 \\
(0.151)\end{array}$ & $\begin{array}{l}0.133^{* * * *} \\
(0.039)\end{array}$ & $\begin{array}{l}-0.325^{* * * *} \\
(0.027)\end{array}$ \\
\hline Secondary & $\begin{array}{l}0.001 \\
(0.002)\end{array}$ & $\begin{array}{l}0.258^{* *} \\
(0.112)\end{array}$ & $\begin{array}{l}0.099 * * * \\
(0.028)\end{array}$ & $\begin{array}{l}-0.219^{* * * *} \\
(0.021)\end{array}$ \\
\hline Rural & $\begin{array}{l}0.003 \\
(0.002)\end{array}$ & $\begin{array}{l}-0.064 \\
(0.095)\end{array}$ & $\begin{array}{l}-0.036 \\
(0.026)\end{array}$ & $\begin{array}{l}0.003 \\
(0.016)\end{array}$ \\
\hline Oil prices & $\begin{array}{l}0.004 \text { *** } \\
(0.000)\end{array}$ & & & \\
\hline Diplomatic exchange & & $\begin{array}{l}-0.704 * * * \\
(0.197)\end{array}$ & & \\
\hline Conflict & & & $\begin{array}{l}0.232 * * * \\
(0.048)\end{array}$ & \\
\hline Illegal status & & & & $\begin{array}{l}-0.594 * * * \\
(0.070)\end{array}$ \\
\hline Legal status & & & & $\begin{array}{l}0.130 * * * \\
(0.044)\end{array}$ \\
\hline Observations & 14,103 & 1,940 & 1,849 & 8,269 \\
\hline Parental controls & Yes & Yes & Yes & Yes \\
\hline Decades of migration dummies & Yes & Yes & Yes & No \\
\hline Labor market controls in Egypt & No & No & No & Yes \\
\hline
\end{tabular}

Robust standard errors in parentheses. *** $p<0.01$; ** $p<0.05 ; * p<0.1$

Data comes from the 2018 ELMPS survey. Equation 1 is the probability of temporary migration. Equation 2 is the probability of undocumented migration. Equation 3 is the probability of return migration. Equation 4 models the logarithm of hourly wages upon return. For identification of equation (1), we use the inflation adjusted historical oil prices (in US dollars). For identification of equation (2), we use diplomatic exchange between Egypt and the countries of destination of Egyptian migrants at time of migration. It is a dummy variable equal to zero if there is no evidence of diplomatic exchange neither in Egypt nor in the country of destination and is equal to one if there is evidence of diplomatic exchange either in Egypt or in the country of destination at the level of chargé d'affaires, minister, ambassador, or other. For identification of equation (3), we use the number of active armed conflicts that is both country and year specific from the Uppsala Conflict Data Project (UCDP). Equation (4) estimates the effect of illegality on the logarithm of hourly wages, unconditional on return migration. The predicted logarithm of hourly wages for non-migrants, and migrants with legal and illegal status is reported in the last row 
Table 19 Dynamics of the effects using 2018 data. Estimating the effect of migrants' legal status on wages after return, unconditional on return (continued)

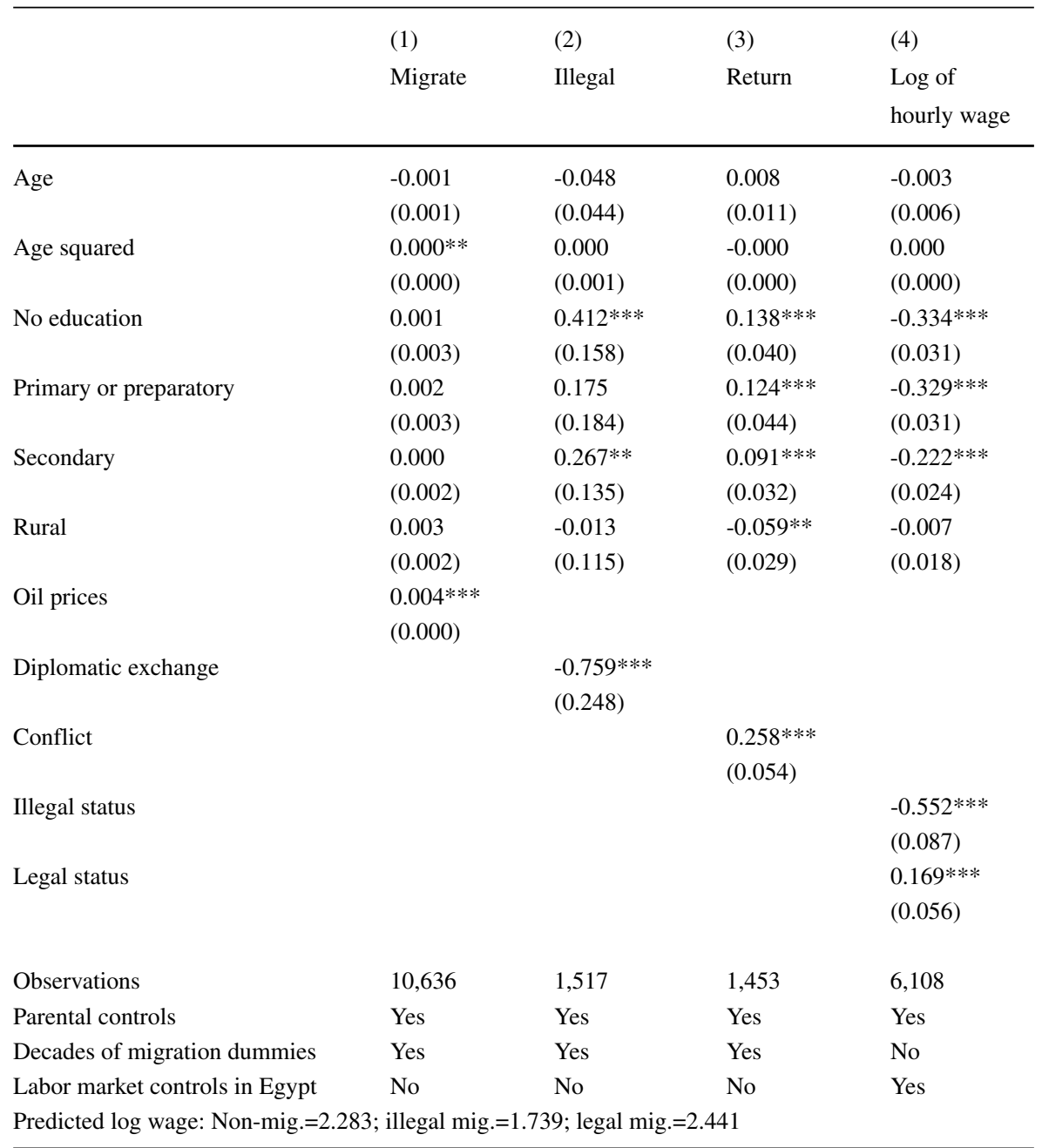

Robust standard errors in parentheses. *** $p<0.01 ; * * p<0.05 ; * p<0.1$

Data comes from the 2018 ELMPS survey. Our analysis is restricted to individuals who were also interviewed in 2012. Equation 1 is the probability of temporary migration. Equation 2 is the probability of undocumented migration. Equation 3 is the probability of return migration. Equation 4 models the logarithm of hourly wages upon return. For identification of equation (1), we use the inflation adjusted historical oil prices (in US dollars). For identification of equation (2), we use diplomatic exchange between Egypt and the countries of destination of Egyptian migrants at time of migration. It is a dummy variable equal to zero if there is no evidence of diplomatic exchange neither in Egypt nor in the country of destination and is equal to one if there is evidence of diplomatic exchange either in Egypt or in the country of destination at the level of chargé d'affaires, minister, ambassador, or other. For identification of equation (3), we use the number of active armed conflicts that is both country and year specific from the Uppsala Conflict Data Project (UCDP). Equation (4) estimates the effect of illegality on the logarithm of hourly wages, unconditional on return migration. The predicted logarithm of hourly wages for non-migrants, and migrants with legal and illegal status is reported in the last row 
Table 20 Voluntary versus involuntary return. Estimating the effect of migrants' legal status on hourly wages after return, unconditional on return migration (continued)

\begin{tabular}{|c|c|c|c|c|c|}
\hline & $\begin{array}{l}\text { (1) } \\
\text { Migrate }\end{array}$ & $\begin{array}{l}\text { (2) } \\
\text { Illegal }\end{array}$ & $\begin{array}{l}\text { (3) } \\
\text { Return }\end{array}$ & $\begin{array}{l}\text { Voluntary } \\
\text { (4a) } \\
\text { Log of } \\
\text { hourly wage }\end{array}$ & $\begin{array}{l}\text { Involuntary } \\
(4 b) \\
\text { Log of } \\
\text { hourly wage }\end{array}$ \\
\hline Age & $\begin{array}{l}0.012 * * * \\
(0.001)\end{array}$ & $\begin{array}{l}-0.074 * * \\
(0.034)\end{array}$ & $\begin{array}{l}-0.014 * * \\
(0.006)\end{array}$ & $\begin{array}{l}-0.001 \\
(0.005)\end{array}$ & $\begin{array}{l}-0.001 \\
(0.005)\end{array}$ \\
\hline Age squared & $\begin{array}{l}-0.000 * * * \\
(0.000)\end{array}$ & $\begin{array}{l}0.001^{*} \\
(0.000)\end{array}$ & $\begin{array}{l}0.000^{* * * *} \\
(0.000)\end{array}$ & $\begin{array}{l}0.000^{* *} \\
(0.000)\end{array}$ & $\begin{array}{l}0.000 * * \\
(0.000)\end{array}$ \\
\hline No education & $\begin{array}{l}0.019 * * * \\
(0.004)\end{array}$ & $\begin{array}{l}0.493 * * * \\
(0.118)\end{array}$ & $\begin{array}{l}-0.030 \\
(0.021)\end{array}$ & $\begin{array}{l}-0.445^{* * * *} \\
(0.026)\end{array}$ & $\begin{array}{l}-0.452 * * * \\
(0.026)\end{array}$ \\
\hline Primary or preparatory & $\begin{array}{l}0.032 * * * \\
(0.004)\end{array}$ & $\begin{array}{l}0.476 * * * \\
(0.126)\end{array}$ & $\begin{array}{l}0.049 * * \\
(0.022)\end{array}$ & $\begin{array}{l}-0.419 * * * \\
(0.025)\end{array}$ & $\begin{array}{l}-0.423 * * * \\
(0.025)\end{array}$ \\
\hline Secondary & $\begin{array}{l}0.017 * * * \\
(0.003)\end{array}$ & $\begin{array}{l}0.362 * * * \\
(0.103)\end{array}$ & $\begin{array}{l}0.034 * \\
(0.017)\end{array}$ & $\begin{array}{l}-0.284 * * * \\
(0.020)\end{array}$ & $\begin{array}{l}-0.290 * * * \\
(0.020)\end{array}$ \\
\hline Rural & $\begin{array}{l}0.009 * * * \\
(0.003)\end{array}$ & $\begin{array}{l}0.261 * * * \\
(0.084)\end{array}$ & $\begin{array}{l}0.009 \\
(0.015)\end{array}$ & $\begin{array}{l}-0.028^{*} \\
(0.016)\end{array}$ & $\begin{array}{l}-0.030^{*} \\
(0.016)\end{array}$ \\
\hline Oil prices & $\begin{array}{l}0.013 * * * \\
(0.000)\end{array}$ & & & & \\
\hline Diplomatic exchange & & $\begin{array}{l}-0.236^{* *} \\
(0.104)\end{array}$ & & & \\
\hline Conflict & & & $\begin{array}{l}0.047 * * * \\
(0.013)\end{array}$ & & \\
\hline Illegal status & & & & $\begin{array}{l}-0.216^{* * * *} \\
(0.061)\end{array}$ & $\begin{array}{l}-0.118 \\
(0.089)\end{array}$ \\
\hline Legal status & & & & $\begin{array}{l}0.192 * * * \\
(0.046)\end{array}$ & $\begin{array}{l}0.106^{* *} \\
(0.042)\end{array}$ \\
\hline Observations & 14,879 & 1,955 & 2,071 & 7,968 & 7,891 \\
\hline Parental controls & Yes & Yes & Yes & Yes & Yes \\
\hline Decades of migration dummies & Yes & Yes & Yes & No & No \\
\hline Labor market controls in Egypt & No & No & No & Yes & Yes \\
\hline \multicolumn{5}{|c|}{ Predicted log wage (4a): Non-mig. $=1.516$; illegal mig. $=1.349$; legal mig. $=1.786$} & \\
\hline
\end{tabular}

Robust standard errors in parentheses. *** $p<0.01$; ** $p<0.05 ; * p<0.1$

Equation 1 is the probability of temporary migration. Equation 2 is the probability of undocumented migration. Equation 3 is the probability of return migration. Equation 4 models the logarithm of hourly wages upon return. For identification of equation (1), we use the inflation adjusted historical oil prices (in US dollars). For identification of equation (2), we use the diplomatic exchange, which is the diplomatic representation of each country of destination of Egyptian migrants in Egypt at time of migration. It is a dummy variable equal to zero if there is no evidence of diplomatic exchange and is equal to one if there is evidence of diplomatic exchange at the level of chargé d'affaires, minister, ambassador, or other. For identification of equation (3), we use the number of active armed conflicts that is both country and year specific from the Uppsala Conflict Data Project (UCDP). Equations (4a) and (4b) estimate the effect of illegality on the logarithm of hourly wages, conditional on return migration. We estimate two models separately. In equation (4a), we consider voluntary return migration, while in equation (4b), we consider involuntary return migration. The predicted logarithm of hourly wages for non-migrants, and migrants with legal and illegal status is reported in the last row 


\section{Appendix 2. Data appendix}

\subsection{The correlates of war diplomatic exchange dataset}

The Diplomatic Exchange dataset captures diplomatic representation at the level of chargé d'affaires, minister, and ambassador between states from 1817 to 2005. The dataset covers all members of the Correlates of War (COW) interstate system. The data is hosted on the COW website. For the post-World War II era, the data is collected from various data sources including Europa World Year Book series, ministries of foreign affairs of various countries, Statesman's Year Book, and the Code Diplomatique.

In this paper, we rely on the most recent version of the data-the 2006 version (Bayer 2006). The 2006 version includes information for the following years: $1817,1824,1827,1832,1836,1840$, every 5 years between 1844 and 1914, every 5 years between 1920 and 1940, and every 5 years between 1950 and 2005. The data is therefore available every 5 years for the period we cover in our analysis (from 1960 onward). The dyadic data describes the level of diplomatic representation and diplomatic exchange between members in the COW system.

For each pair of countries (country 1, country 2) in the COW interstate system, the diplomatic exchange dataset provides information on the following 3 variables: the diplomatic representation of country 1 in country 2 , the diplomatic representation of country 2 in country 1 , and if any diplomatic representation between country 1 and country 2 exists.

The dyadic data captures the level of diplomatic representation between countries. The diplomatic exchange variables that describe the level of diplomatic representation for a given pair of countries is coded as 0 if there is no evidence of diplomatic exchange, 1 if diplomatic representation is at the level of chargé d'affaires, 2 if diplomatic representation is at the level of minister, 3 if diplomatic representation is at the level of ambassador, and 9 for all other levels of diplomatic representation.

In our analysis, we use dummy variable indicators to capture any diplomatic representation (whether it is a the level of chargé d'affaires, minister, or ambassador) in Egypt for each country of destination of Egyptian migrants. For robustness checks, we also use two alternative definitions. The first one captures instead the diplomatic representation of Egypt in each country of destination of Egyptian migrants, while the second alternative definition captures the existence of any diplomatic exchange between the two countries. It is a dummy variable coded as 0 if neither side was represented in the other side and coded as 1 if at least one side was represented in the other side.

\subsection{The Uppsala Conflict Data Project}

The Monadic Conflict Onset and Incidence dataset comes from the Uppsala Conflict Data Project (UCDP). In this paper, we rely on the 2013 version of the dataset (Themnér and Wallensteen 2014; Gleditsch et al. 2002). The dataset contains annual observations of all states in the international system between 1946 and 2013. The 
data is monadic - each observation corresponds to a country-year. It contains information on all internal and internationalized internal armed conflicts, where conflicts are located according to the government side in the conflict.

Two versions of the data exist: one containing conflict level variables and one containing dyadic data. The difference between the two datasets is that the former treats all variables at UCDP conflict level, while the latter treats all variables at the UCDP conflict dyad level. For example, if there is one active UCDP conflict in a given country, the number of total conflicts in this country-year will be equal to 1 in the conflict level dataset. However, in the dyad version of the data, if this conflict involves different actors, the data will instead report the number of actors involved in the UCDP conflict.

In this paper, we rely on the conflict level dataset, which is at the country-year level. Importantly, we use information on the total number of active conflicts for a given country-year from the UCDP dataset. The Monadic Conflict Onset and Incidence data also contains additional information on the following indicators, among others: the incidence of intrastate conflict, which is coded 1 in all country-years with at least one active conflict, the onset of intrastate conflict, which is coded 1 if the country-year contains a new conflict, and the intensity level of the conflict in the country-year: minor conflict ( $>25$ deaths) versus war ( $>1000$ deaths).

Open Access This article is licensed under a Creative Commons Attribution 4.0 International License, which permits use, sharing, adaptation, distribution and reproduction in any medium or format, as long as you give appropriate credit to the original author(s) and the source, provide a link to the Creative Commons licence, and indicate if changes were made. The images or other third party material in this article are included in the article's Creative Commons licence, unless indicated otherwise in a credit line to the material. If material is not included in the article's Creative Commons licence and your intended use is not permitted by statutory regulation or exceeds the permitted use, you will need to obtain permission directly from the copyright holder. To view a copy of this licence, visit http://creativecommons.org/licenses/by/4.0/.

\section{References}

Abrego LJ (2011) Legal consciousness of undocumented Latinos: fear and stigma as barriers to claimsmaking for first-and 1.5-generation immigrants. Law \& Society Review 45(2):337-370

Ambrosini JW, Mayr K, Peri G, Radu D (2015) The selection of migrants and returnees in Romania: evidence and long-run implications. Economics of Transition 23(4):753-793

Assaad R, Krafft C (2013) The Egypt labor market panel survey: introducing the 2012 round. IZA Journal of Labor \& Development 2(1):8

Awad I, Aziz NA (2017) Egyptian irregular migration in the GCC countries. In: Skillful survivals: irregular migration to the Gulf. Cambridge: Gulf Research Centre Cambridge

Azose JJ, Raftery AE (2019) Estimation of emigration, return migration, and transit migration between all pairs of countries. Proceedings of the National Academy of Sciences 116(1):116-122

Bayer R (2006) Diplomatic exchange data set, v2006. 1. http://correlatesofwar.org

Bean FD, Lowell BL, Taylor LJ (1988) Undocumented Mexican immigrants and the earnings of other workers in the United States. Demography 25(1):35-52

Borjas GJ, Freeman RB, Lang K (1991) Undocumented Mexican-born workers in the United States: how many, how permanent? In: Immigration, trade, and the labor market, pp 77-100. University of Chicago Press

Brodmann S, Pouget Y, Gatti R (2010) Labor mobility in the Middle East and North Africa: challenges and opportunities. World Bank, Washington, DC 
Carletto C, Kilic T (2011) Moving up the ladder? The impact of migration experience on occupational mobility in Albania. J Dev Stud 47(6):846-869

Co CY, Gang IN, Yun M-S (2000) Returns to returning. J Popul Econ 13(1):57-79

Coniglio ND, De Arcangelis G, Serlenga L (2009) Intentions to return of clandestine migrants: the perverse effect of illegality on skills. Rev Dev Econ 13(4):641-657

De Bel-Air F (2016) Migration profile: Egypt, Migration Policy Centre, Policy Briefs, 2016/01, EUI.

De Coulon A, Piracha M (2005) Self-selection and the performance of return migrants: the source country perspective. J Popul Econ 18(4):779-807

De Vreyer P, Gubert F, Robilliard A-S (2010) Are there returns to migration experience? An empirical analysis using data on return migrants and non-migrants in West Africa. Annals of Economics and Statistics/Annales d'économie et de statistique, pp 307-328

Devillanova C, Fasani F, Frattini T (2018) Employment of undocumented immigrants and the prospect of legal status: evidence from an amnesty program. ILR Review 71(4):853-881

Dustmann C, Fasani F, Speciale B (2017) Illegal migration and consumption behavior of immigrant households. J Eur Econ Assoc 15(3):654-691

Elmallakh N, Wahba J (2021) Return migrants and the wage premium: does the legal status of migrants matter?. IZA Discussion Paper No. 14492

Elmallakh N, Wahba J (2021) Upward or downward: occupational mobility and return migration. World Dev, 137

Gleditsch NP, Wallensteen P, Eriksson M, Sollenberg M, Strand H (2002) Armed conflict 1946-2001: a new dataset. J Peace Res 39(5):615-637

Gleeson S, Gonzales RG (2012) When do papers matter? An institutional analysis of undocumented life in the United States. Int Migr 50(4):1-19

Gonzales RG (2011) Learning to be illegal: undocumented youth and shifting legal contexts in the transition to adulthood. Am Sociol Rev 76(4):602-619

Gonzalez-Barrera A (2015) More Mexicans leaving than coming to the US, Washington

Hall M, Greenman E (2015) The occupational cost of being illegal in the United States: legal status, job hazards, and compensating differentials. Int Migr Rev 49(2):406-442

Hanson GH (2006) Illegal migration from Mexico to the United States. J Econ Lit 44(4):869-924

Kemnitz A, Mayr K (2012) Return migration and illegal immigration control. Norface Migration Discussion Paper No. 2012-40

Kossoudji SA, Cobb-Clark DA (2002) Coming out of the shadows: learning about legal status and wages from the legalized population. J Labor Econ 20(3):598-628

Krafft C, Assaad R, Rahman KW (2019) Introducing the Egypt Labor Market Panel Survey 2018. Economic Research Forum Working Paper No. 1360

Lacuesta A (2010) A revision of the self-selection of migrants using returning migrant's earnings. Annals of Economics and Statistics/Annales d'Économie et de Statistique, pp 235-259

Lavy V (1984) The economic embargo of Egypt by Arab states: myth and reality. Middle East Journal 38(3):419-432

Mann J (2012) King Faisal and the challenge of Nasser's revolutionary ideology. Middle Eastern Studies 48(5):749-764

Massey DS, Pren KA, Durand J (2016) Why border enforcement backfired. Am J Sociol 121(5):15571600

Massey DS, Singer A (1995) New estimates of undocumented Mexican migration and the probability of apprehension. Demography 32(2):203-213

OAMDI (2016) Labor Market Panel Surveys (LMPS). http://www.erfdataportal.com/index.php/catalog/ 161

OECD (2018) International migration outlook 2018. https:/www.oecd-ilibrary.org/content/publication/ migr_outlook-2018-en

Orrenius PM, Zavodny M (2003) Do amnesty programs reduce undocumented immigration? Evidence from IRCA. Demography 40(3):437-450

Orrenius PM, Zavodny M (2005) Self-selection among undocumented immigrants from Mexico. J Dev Econ 78(1):215-240

Ortega F, Hsin A (2018) Occupational barriers and the labor market penalty from lack of legal status. IZA Discussion Paper No. 11680

Patler C, Pirtle WL (2018) From undocumented to lawfully present: do changes to legal status impact psychological wellbeing among latino immigrant young adults? Social Science \& Medicine 199:39-48 
Phillips JA, Massey DS (1999) The new labor market: immigrants and wages after IRCA. Demography 36(2):233-246

Reinhold S, Thom K (2013) Migration experience and earnings in the Mexican labor market. J Hum Resour 48(3): 768-820

Reyes BI (2001) Immigrant trip duration: the case of immigrants from Western Mexico. Int Migr Rev 35(4):1185-1204

Rivera-Batiz FL (1999) Undocumented workers in the labor market: an analysis of the earnings of legal and illegal Mexican immigrants in the United States. J Popul Econ 12(1):91-116

Roodman D (2011) Fitting fully observed recursive mixed-process models with cmp. The Stata Journal 11(2):159-206

Schloenhardt A (2014) Migrant smuggling in Asia: current trends and related challenges. Routledge Handbook of Transnational Criminal Law, pp 409-433

Schluter C, Wahba J (2009) Illegal migration, wages, and remittances: semi-parametric estimation of illegality effects. IZA Discussion Paper No. 4527

Sicherman N, Galor O (1990) A theory of career mobility. J Polit Econ 98(1):169-192

Sullivan P (1999) Contrary views of economic diplomacy in the Arab world: Egypt. Arab Stud Q, pp 6593

Themnér L, Wallensteen P (2014) Armed conflicts, 1946-2013. J Peace Res 51(4):541-554

Vinogradova A (2016) Illegal immigration, deportation policy, and the optimal timing of return. J Popul Econ 29(3):781-816

Wahba J (2014) Return migration and economic development. In: International handbook on migration and economic development. Edward Elgar Publishing

Wahba J (2015) Selection, selection, selection: the impact of return migration. J Popul Econ 28(3):535563

Wahba J, Zenou Y (2012) Out of sight, out of mind: migration, entrepreneurship and social capital. Reg Sci Urban Econ 42(5):890-903

Publisher's note Springer Nature remains neutral with regard to jurisdictional claims in published maps and institutional affiliations. 